\title{
Article
}

\section{New Succinimides with Potent Anticancer Activity: Synthesis, Activation of Stress Signaling Pathways and Characterization of Apoptosis in Leukemia and Cervical Cancer Cells}

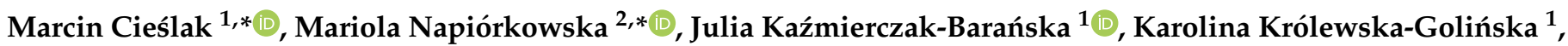 \\ Anna Hawrył ${ }^{3}{ }^{(\mathbb{*}}$, Iwona Wybrańska ${ }^{4}$ and Barbara Nawrot ${ }^{1}$ (D) \\ 1 Centre of Molecular and Macromolecular Studies, Department of Bioorganic Chemistry, Polish Academy \\ of Sciences, 112 Sienkiewicza, 90-363 Lodz, Poland; juliakazmierczak@tlen.pl (J.K.-B.); \\ kkrolews@cbmm.lodz.pl (K.K.-G.); bnawrot@cbmm.lodz.pl (B.N.) \\ 2 Department of Biochemistry, Faculty of Medicine, Medical University of Warsaw, 1 Banacha, \\ 02-097 Warsaw, Poland \\ 3 Department of Inorganic Chemistry, Faculty of Pharmacy, Medical University of Lublin, Chodźki 4a, \\ 20-093 Lublin, Poland; anna.hawryl@umlub.pl \\ 4 Clinical Biochemistry, Department of Genetics and Nutrigenomics, Faculty of Medicine, \\ Jagiellonian University Medical College, 15a Kopernika, 31-501 Kraków, Poland; mbwybran@cyf-kr.edu.pl \\ * Correspondence: marcin@cbmm.lodz.pl (M.C.); mariola.krawiecka@wum.edu.pl (M.N.); \\ Tel.: +48-42-680-32-30 (M.C.); +48-22-572-06-39 (M.N.)
}

Citation: Cieślak, M.; Napiórkowska, M.; Kaźmierczak-Barańska, J.; Królewska-Golińska, K.; Hawrył, A.; Wybrańska, I.; Nawrot, B. New Succinimides with Potent Anticancer Activity: Synthesis, Activation of Stress Signaling Pathways and Characterization of Apoptosis in Leukemia and Cervical Cancer Cells. Int. J. Mol. Sci. 2021, 22, 4318.

https: / / doi.org/10.3390/ijms22094318

Academic Editor: Angela Stefanachi

Received: 4 March 2021

Accepted: 19 April 2021

Published: 21 April 2021

Publisher's Note: MDPI stays neutral with regard to jurisdictional claims in published maps and institutional affiliations.

Copyright: (c) 2021 by the authors. Licensee MDPI, Basel, Switzerland. This article is an open access article distributed under the terms and conditions of the Creative Commons Attribution (CC BY) license (https:// creativecommons.org/licenses/by/ $4.0 /)$.

\begin{abstract}
Based on previously identified dicarboximides with significant anticancer and immunomodulatory activities, a series of 26 new derivatives were designed and synthesized by the Diels-Alder reaction between appropriate diene and maleimide or hydroxymaleimide moieties. The resulting imides were functionalized with alkanolamine or alkylamine side chains and subsequently converted to their hydrochlorides. The structures of the obtained compounds were confirmed by $1 \mathrm{H}$ and 13C NMR and by ESI MS spectral analysis. Their cytotoxicity was evaluated in human leukemia (K562, MOLT4), cervical cancer (HeLa), and normal endothelial cells (HUVEC). The majority of derivatives exhibited high to moderate cytotoxicity and induced apoptosis in K562 cells. Microarray gene profiling demonstrated upregulation of proapoptotic genes involved in receptor-mediated and mitochondrial cell death pathways as well as antiapoptotic genes involved in NF-kB signaling. Selected dicarboximides activated JNK and p38 kinases in leukemia cells, suggesting that MAPKs may be involved in the regulation of apoptosis. The tested dicarboximides bind to DNA as assessed by a plasmid DNA cleavage protection assay. The selected dicarboximides offer new scaffolds for further development as anticancer drugs.
\end{abstract}

Keywords: dicarboximides; chemical synthesis; cytotoxicity; apoptosis; kinases; anticancer; gene profiling; SAR

\section{Introduction}

Cancer diseases are an important problem in the clinical medicine and pharmacology of the 21st century. Annually, more than eight million people die from cancer worldwide. In Europe alone, three million new cases are diagnosed and 1.7 million people die from cancer. In Poland, cancer kills nearly 110,000 people, of which about 100,000 die from malignant tumors. It is estimated that the ongoing increase in the incidence of cancer will make it the main cause of death in Poland and worldwide in the coming decades [1,2]. Despite recent progress in cancer treatment (for example development of immune checkpoint inhibitors), chemotherapy (either alone or in combination with radiotherapy or biologic drugs) still remains the first-line treatment in the majority of cancers. Therefore, new cytotoxic low molecular weight compounds are actively sought and developed because they may offer 
better pharmacokinetic properties and/or less toxic profiles compared to already applied chemotherapeutics (for example platinum compounds or taxanes).

Dicarboximides comprise a large group of compounds and can be divided into four categories: succinimides, maleimides, glutarimides, and phthalimides. Succinimides and phthalimides offer a wide range of chemical and biological applications. They are also very important from a therapeutic perspective, as they are used as drugs (for example, anticonvulsant-ethosuximide) or tested as drug candidates. These derivatives show antifungal, antibacterial, antidepressant, or analgesic activities. Several reports describe the antitumor activity of succinimides and phthalimides. Pyridinyl- and quinolinyl-derivatives of succinimide demonstrated antitumor activity in leukemia cells by inhibition of DNA synthesis [3]. Trifluoromethylated mono- and bicyclic succinimides were found to inhibit the growth of myeloma, non-small cell lung cancer, and renal cancer cells [4]. Nbenzylcantharidinamide promoted the degradation of matrix metalloproteinase-9 (MMP-9) mRNA in an antigen R-dependent manner in human hepatocellular carcinoma Hep3B cells. This resulted in decreased expression of MMP-9 and reduced invasion of the highly metastatic Hep3B cells [5]. Benzothiazole derivatives of phthalimide showed significant cytotoxicity and induced apoptosis in human hepatoma (SKHep1), Burkitt's B-cell lymphoma (CA46), and chronic myelogenous leukemia (K562) cells [6]. Dual-acting thiazolidinone derivates of phthalimide with antiproliferative and immunosuppressive activity were also identified. These compounds inhibited the proliferation of cancer cells and blocked the secretion of pro-inflammatory cytokines, for example, TNF- $\alpha$, IL-2, or Il-6 [7]. Probably the best-known phthalimide-based drug is thalidomide ( $\mathrm{N}-\alpha$-phthalimidoglutarimide). This is a synthetic derivative of phthalimide N-substituted with glutarimide. Since 1957, thalidomide has been used as an anti-emetic agent, but in 1961 it was withdrawn from the market because of severe teratogenicity. However, further studies demonstrated the potent anti-angiogenic and anti-inflammatory activity of thalidomide (and its derivativeslenalidomide and pomalidomide), which warranted its return as an essential medicine. Currently, thalidomide is used as an anti-cancer drug (for multiple myeloma), for the treatment of myelodysplastic syndrome and inflammatory disorders, like erythema nodosum leprosum [8]. We have previously identified several lead dicarboximides (in particular Ic, Ie, and II, Figure 1) structurally related to succinimides and phthalimides, which exhibited high cytotoxicity and selectivity toward leukemia cells.

We also found that they targeted the ABC50 protein, showed immunomodulatory activity, and induced apoptosis in leukemia cells [9-11]. In particular, compound Ic inhibited endonuclease-catalyzed digestion of DNA, suggesting its interaction with nucleic acids [9] and activated caspase 8 and 9, which are markers of receptor-mediated and mitochondrial apoptotic pathways, respectively [11]. However, the detailed mechanism of apoptosis and the involvement of mitogen-activated protein kinases (MAPKs) were not investigated. These anticancer and immunomodulatory activities of dicarboximides indicate their importance as potential drug candidates and significance for further development.

The main goal of this study was to obtain new derivatives of dicarboximides with decreased lipophilicity and improved anticancer activity as compared to the lead compounds (i.e., Ia-Ie and II). To achieve this aim, we designed, synthesized, and examined the biological activity of new derivatives of dicarboximides. These new derivatives showed potent cytotoxic and proapoptotic activity in cancer cells, and DNA intercalating properties. Microarray analysis of gene expression revealed that dicarboximides upregulated genes involved in receptor-mediated and mitochondrial apoptotic pathways. Interestingly, antiapoptotic genes associated with NF-kB signaling were also upregulated. They also activated stress-induced MAPK signaling pathways in cancer cells. 


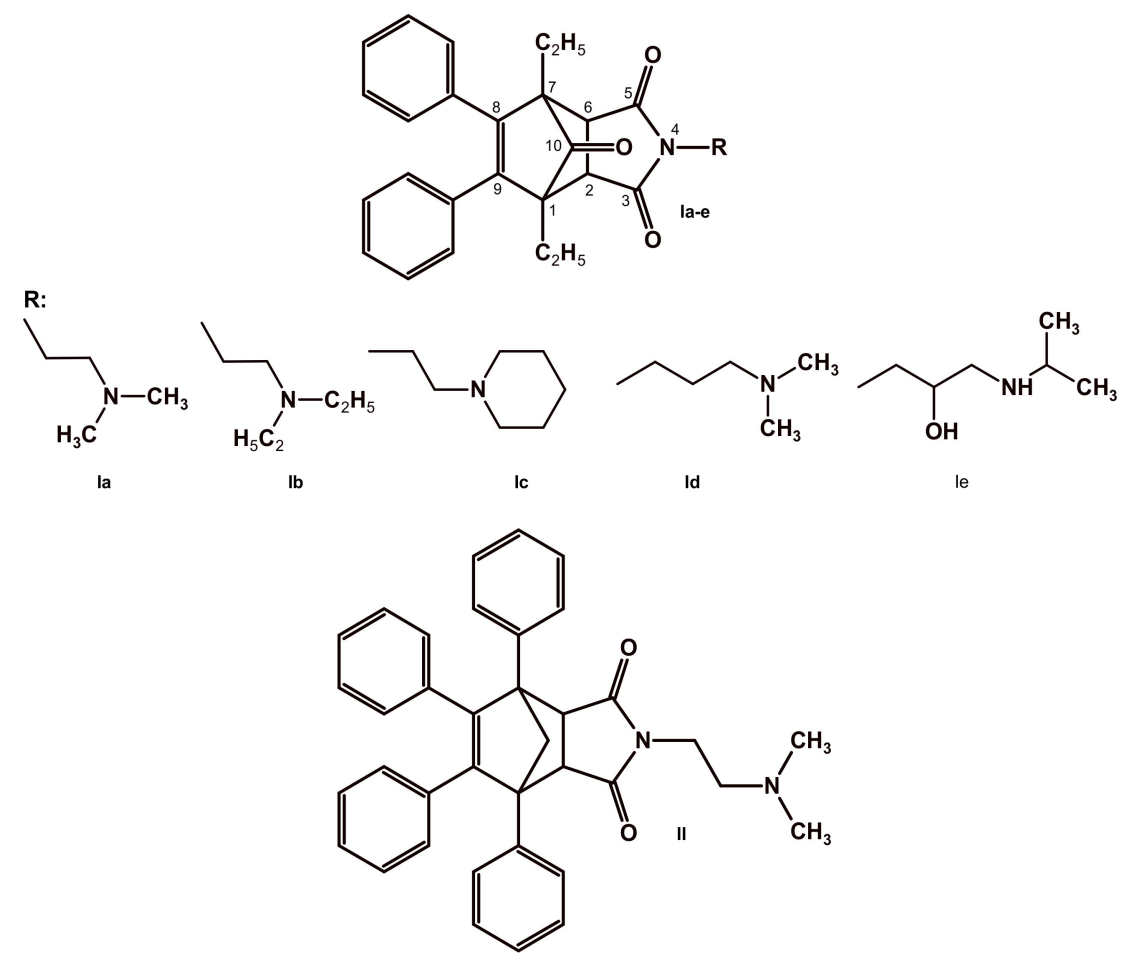

Figure 1. Structures of lead compounds Ia-e and II.

2. Results

2.1. Synthesis

The starting imides 1-3 were obtained in Diels-Alder reactions between appropriate dienes and maleimide, while the compounds 4 and $\mathbf{5}$ were obtained in the reaction with $\mathrm{N}$-(hydroxyethyl)-maleimide (Scheme 1). The epoxy-derivatives were obtained by condensation of starting imides with epichlorohydrin, and the products were condensed with appropriate amines to give alkanolamine derivatives (Scheme 1). In the reaction between imide 1 and 1,2-dichloroethane, the chloroalkyl derivative was obtained and condensed with an appropriate amine (Scheme 1). All obtained amino-derivatives were converted to their hydrochlorides by using methanol saturated with hydrochloride. The lead compounds with the best activity (Ic, Ie, and II) described previously [9] were converted to their acetates by using boiling acetic acid. The structures of new compounds were established by spectroscopic methods (1H NMR, 13C NMR, and HRMS). In this case, ethyl groups in positions 1 and 7 were replaced by methyl groups.

The main goal of the synthetic part was the synthesis of new derivatives of dicarboximides with decreased lipophilicity in comparison to the lead compounds, i.e., Ia-Ie and II. To reduce the lipophilicity of the new dicarboximides, a hydroxyalkyl chain connected with an aliphatic amine was introduced to the imides (Scheme 1). At the same time, the imide scaffold in derivatives from group $\mathbf{2}$ and $\mathbf{3}$ was the same as in lead compounds Ia-Ie and II, respectively (Figure 1). The structure of the imide was changed in derivatives $\mathbf{1} \mathbf{b}-\mathbf{1 g}$. The lipophilicity of new derivatives was calculated using the Osiris Property Explorer program. For some compounds, lipophilicity was determined experimentally by a reversed-phase chromatography (detailed description is given in Materials and Methods and in the Supplementary Data, Table S2). Table 1 summarizes the calculated $(\operatorname{cog} P)$ and experimental $\left(\log k_{w}\right)$ parameters of the lipophilicity of new derivatives. 


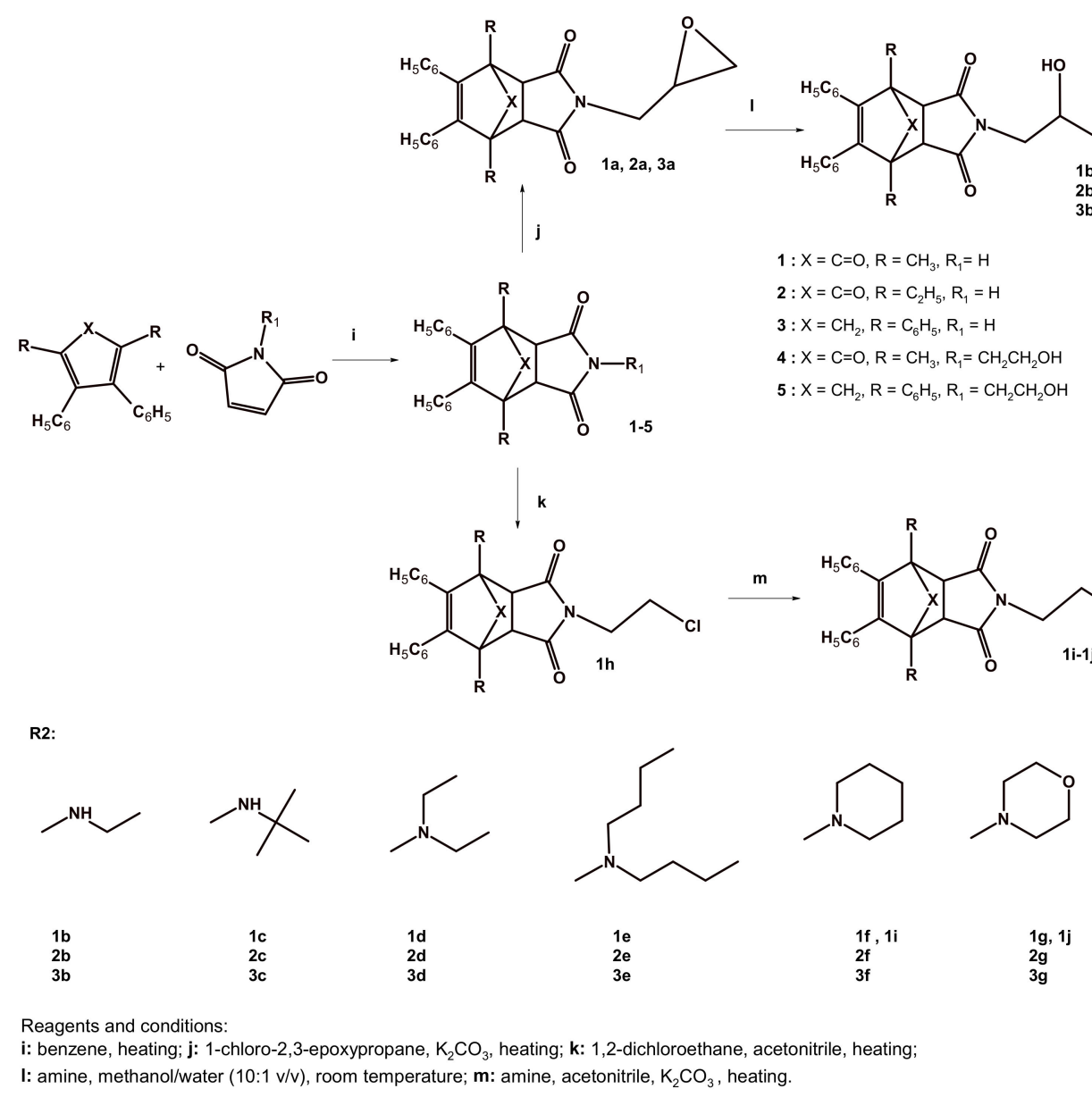

Scheme 1. Synthesis of starting imides, N-alkanolamine and N-alkylamino derivatives of dicarboximides.

In some cases, the new derivatives had lower lipophilicity in comparison to the lead compounds. For example, derivatives of imide 1 had a median $\operatorname{cog} P$ and $\log k_{w}$ of 3.19 and 4.85, respectively, while corresponding values for lead dicarboximides Ia-Ie were 4.27 and 5.05. This decrease in lipophilicity can be attributed to the replacement of ethyl groups by methyl groups in the imide scaffold and the presence of the hydroxyalkyl chain. The introduction of a hydroxyalkyl chain in derivatives from the group of imide 2 resulted in a slight decrease in lipophilicity (median $\operatorname{cog} P$ and $\log k_{w}$ of 4.1 and 5.03, respectively) compared to parent compounds Ia-Ie. However, pronounced exceptions were alkanoldibutylamine derivatives $\mathbf{1 e}$ and $\mathbf{2 e}$, which showed significantly increased lipophilicity. The modifications introduced to imide 3 derivatives did not significantly affect their lipophilicity (median $\operatorname{cog} P$ and $\log k_{w}$ of 5.69 and 6.28, respectively) compared to the lead dicarboximide II $\left(\log P 5.45\right.$ and $\left.\log k_{w} 6.34\right)$.

\subsection{MTT Cytotoxicity Studies}

The cytotoxicity of new derivatives of dicarboximides was tested in HeLa (cervix carcinoma cell line), K562 (myelogenous leukemia cell line), MOLT-4 (Human T-Lymphoid Cell Line), and HUVEC (normal endothelial) cells. First, the viability of cells was determined after $48 \mathrm{~h}$ incubation with the screened compounds used at the concentration of $100 \mu \mathrm{M}$ (data not shown). For compounds that reduced the viability of cancer cells by more than $50 \%$, the $\mathrm{IC}_{50}$ values were determined (Table 2). Cells exposed to $1 \%$ DMSO (as vehicle) served as the control with $100 \%$ survival. Cells treated with $1 \mu \mathrm{M}$ staurosporine served as the internal control of the cytotoxicity experiments (the viability of cancer cells was reduced to $44-49 \%$, data not shown). 
Table 1. Calculated $(\operatorname{cog} P)$ and experimental $\left(\log k_{w}\right)$ parameters of lipophilicity for synthesized compounds. nd-not determined.

\begin{tabular}{|c|c|c|c|c|c|}
\hline Imide Group & Compound & $\begin{array}{c}c \log P \\
\text { (Calculated) }\end{array}$ & $\begin{array}{c}\text { Median } \\
c \log P\end{array}$ & $\begin{array}{c}\log k_{w} \\
\text { (Experimental) }\end{array}$ & $\begin{array}{c}\text { Median } \\
\log k_{w}\end{array}$ \\
\hline \multirow{5}{*}{2} & Ia & 3.82 & \multirow{5}{*}{4.27} & 4.94 & \multirow{5}{*}{5.05} \\
\hline & Ib & 4.63 & & 5.09 & \\
\hline & Ic & 4.95 & & 5.02 & \\
\hline & Id & 4.27 & & 5.05 & \\
\hline & Ie & 4.06 & & 5.17 & \\
\hline \multirow{10}{*}{1} & $1 b$ & 2.48 & \multirow{10}{*}{3.19} & 4.78 & \multirow{10}{*}{4.85} \\
\hline & 1c & 3.22 & & 4.91 & \\
\hline & 1d & 3.15 & & 4.87 & \\
\hline & $1 e$ & 4.97 & & nd & \\
\hline & 1f & 3.47 & & nd & \\
\hline & $1 g$ & 2.31 & & 4.83 & \\
\hline & 4 & 2.69 & & nd & \\
\hline & 1h & 3.84 & & nd & \\
\hline & $\mathbf{1 j}$ & 2.88 & & nd & \\
\hline & $1 \mathbf{i}$ & 4.04 & & nd & \\
\hline \multirow{6}{*}{2} & $2 b$ & 3.39 & \multirow{6}{*}{4.1} & 5.08 & \multirow{6}{*}{5.03} \\
\hline & $2 c$ & 4.13 & & 4.74 & \\
\hline & $2 d$ & 4.06 & & 5.10 & \\
\hline & $2 e$ & 5.88 & & nd & \\
\hline & $2 f$ & 4.38 & & nd & \\
\hline & $2 \mathrm{~g}$ & 3.22 & & 4.98 & \\
\hline 3 & II & 5.45 & & 6.34 & \\
\hline \multirow{7}{*}{3} & $3 b$ & 5.02 & \multirow{7}{*}{5.69} & 6.31 & \multirow{7}{*}{6.28} \\
\hline & $3 c$ & 5.76 & & 6.06 & \\
\hline & $3 d$ & 5.69 & & 6.28 & \\
\hline & $3 e$ & 7.51 & & nd & \\
\hline & $3 f$ & 6.01 & & nd & \\
\hline & $3 g$ & 4.85 & & 6.28 & \\
\hline & 5 & 5.23 & & nd & \\
\hline
\end{tabular}

Test compounds showed significant cytotoxicity toward all tested cancer cell lines. Derivatives of imide 2 and 3 (i.e., $\mathrm{Ic}^{*} \mathrm{CH}_{3} \mathrm{COOH}, \mathrm{Ie}^{*} \mathrm{CH}_{3} \mathrm{COOH}, \mathbf{2 b}-\mathbf{2 g}, 3 \mathrm{c}-\mathbf{3 g}$, 5), possessing the same imide skeleton as the lead compounds, displayed the best activity with $\mathrm{IC}_{50}$ in the range of 1.9-26 $\mu \mathrm{M}$. In the group of derivatives of imide 1, the highest activity was demonstrated by $1 \mathrm{e}$ against all tested cancer cell lines $\left(\mathrm{IC}_{50}\right.$ of $3.2,5.8$, and $8 \mu \mathrm{M}$, respectively). It is noteworthy that derivatives $\mathbf{1 b}, \mathbf{1 h}$, and $\mathbf{1 i}$ were the most toxic to MOLT-4 cells ( $\mathrm{IC}_{50}$ of 7,20 , and $15 \mu \mathrm{M}$, respectively), whereas compound $\mathbf{1 f}$ was cytotoxic to $\mathrm{K} 562$ (IC 50 of $18 \mu \mathrm{M}$ ). Other derivatives of this class showed moderate activity ( $\mathrm{IC}_{50}$ in the range of 28-105 $\mu \mathrm{M})$. Similar cytotoxicity as for cancer cells was observed in normal endothelial cells, with $\mathrm{IC}_{50}$ values in the range of $0.3-64 \mu \mathrm{M}$.

\subsection{Activation of Apoptosis and Expression Profile of Apoptotic Genes}

Six derivatives of dicarboximides, i.e., $3 \mathbf{c}, \mathbf{3 d}, \mathbf{3 f}, \mathbf{2 c}, \mathbf{2 d}$, and $\mathbf{2 f}$, with the highest cytotoxicity against $\mathrm{K} 562$ leukemia cells $\left(\mathrm{IC}_{50}<6 \mu \mathrm{M}\right)$ and with the same alkanolamine fragment in the structure were further evaluated for the ability to induce apoptosis in cancer cells. Caspases 3 and 7 (caspase 3/7) are markers of apoptosis, and their activity was upregulated during this process. K562 cells were treated with 1\% DMSO (negative control), $1 \mu \mathrm{M}$ staurosporine (a strong inducer of apoptosis, a positive control), or a test compound at the concentration of $5 \times \mathrm{IC}_{50}$. After incubation for $18 \mathrm{~h}, \mathrm{~K} 562$ cells were lysed and the activity of caspase $3 / 7$ was measured using a profluorescent peptide substrate. Staurosporine strongly activated caspase 3/7 in K562 cells, while DMSO had no effect (Figure 2). We 
also observed a significant increase in the activity of caspase $3 / 7$ in the presence of all tested dicarboximides. Particularly, derivatives $\mathbf{2 c}, \mathbf{2 d}$, and $\mathbf{2 f}$ were potent activators of apoptosis, as they induced an over eight-fold increase in caspase activity compared to control. Incubation of cells with compounds $\mathbf{3 c}, \mathbf{3 d}$, and $\mathbf{3 f}$ activated caspase $3 / 7$ to a lesser extent. Altogether, these data suggest that the cytotoxicity of new derivatives of dicarboximides is most likely due to the induction of apoptosis in the chronic myelogenous leukemia (CML) K562 cells.

Table 2. The $\mathrm{IC}_{50}$ values $(\mu \mathrm{M})$ for dicarboximides after $48 \mathrm{~h}$ incubation with a given cell line. Average values and standard deviations (in parenthesis) from three experiments are shown. Compounds were used as $\mathrm{HCl}$ salts except for $\mathbf{I} \mathbf{c}$ *, Ie *, and II * which were used as $\mathrm{CH}_{3} \mathrm{COOH}$ salts.

\begin{tabular}{ccccc}
\hline Compound & HeLa & K562 & MOLT-4 & HUVEC \\
\hline $\mathbf{1 b}$ & $30(7.5)$ & $32(8.3)$ & $7(1.8)$ & $20(2.4)$ \\
$\mathbf{1 c}$ & $26(5.2)$ & $28(6.7)$ & $28(5)$ & $23(3.2)$ \\
$\mathbf{1 d}$ & $59(8.9)$ & $39(9.4)$ & $37(4.4)$ & $22(3.3)$ \\
$\mathbf{1 e}$ & $3.2(0.4)$ & $5.8(1.0)$ & $8(0.9)$ & $30(4.2)$ \\
$\mathbf{1 f}$ & $55(17.6)$ & $18(3.8)$ & $40(10.8)$ & $21(1.6)$ \\
$\mathbf{1 g}$ & $>100$ & $>100$ & $>100$ & nd \\
$\mathbf{4}$ & $61(14.8)$ & $105(15.2)$ & $71(14.8)$ & $56(4.8)$ \\
$\mathbf{1 h}$ & nd & nd & $20(4.7)$ & $64(7)$ \\
$\mathbf{1 j}$ & $>100$ & $>100$ & $>100$ & nd \\
$\mathbf{1 i}$ & $52(19.2)$ & $30(4.1)$ & $15(1.2)$ & $23(1.8)$ \\
$\mathbf{I c}{ }^{*}$ & $18(3.1)$ & $20(3.4)$ & $15(3.2)$ & $15(6.3)$ \\
$\mathbf{I e}$ & $10(2.6)$ & $8(1.7)$ & $15(2.3)$ & $3.5(0.2)$ \\
$\mathbf{2 b}$ & $26(5.6)$ & $8(1.5)$ & $14(0.9)$ & $3.4(0.3)$ \\
$\mathbf{2 c}$ & $3.2(0.8)$ & $4(0.5)$ & $2.5(0.1)$ & $3.3(0.2)$ \\
$\mathbf{2 d}$ & $18(4.9)$ & $5.8(1.2)$ & $14(2.6)$ & $3.6(0.2)$ \\
$\mathbf{2 e}$ & $19(4.5)$ & $4.1(0.5)$ & $3.1(0.2)$ & $1.2(0.06)$ \\
$\mathbf{2 f}$ & $5.1(0.7)$ & $3.9(0.5)$ & $3.4(0.3)$ & $3.1(0.3)$ \\
$\mathbf{2 g}$ & $23(3.6)$ & $20(1.4)$ & $18(2.5)$ & $17(1.6)$ \\
$\mathbf{I I}{ }^{*}$ & $20(2.4)$ & $16(4.5)$ & $18(5)$ & $4(0.5)$ \\
$\mathbf{3 b}$ & $>100$ & $>100$ & $>100$ & nd \\
$\mathbf{3 c}$ & $2(0.4)$ & $2(0.6)$ & $2.6(0.3)$ & $0.4(0.03)$ \\
$\mathbf{3 d}$ & $1.9(0.6)$ & $3.2(0.4)$ & $2.2(0.3)$ & $0.3(0.02)$ \\
$\mathbf{3 e}$ & $40(8.4)$ & $6(1.4)$ & $5.4(0.5)$ & $7(0.6)$ \\
$\mathbf{3 f}$ & $3(0.9)$ & $3(0.6)$ & $3(1)$ & $0.4(0.02)$ \\
$\mathbf{3 g}$ & $120(16)$ & $31(3.6)$ & $5.2(0.9)$ & $17(1.8)$ \\
$\mathbf{5}$ & $8(1)$ & $6.2(1)$ & $2.1(0.1)$ & $0.7(0.08)$ \\
\hline
\end{tabular}

* denotes compounds as acetate salts; nd-not determined.

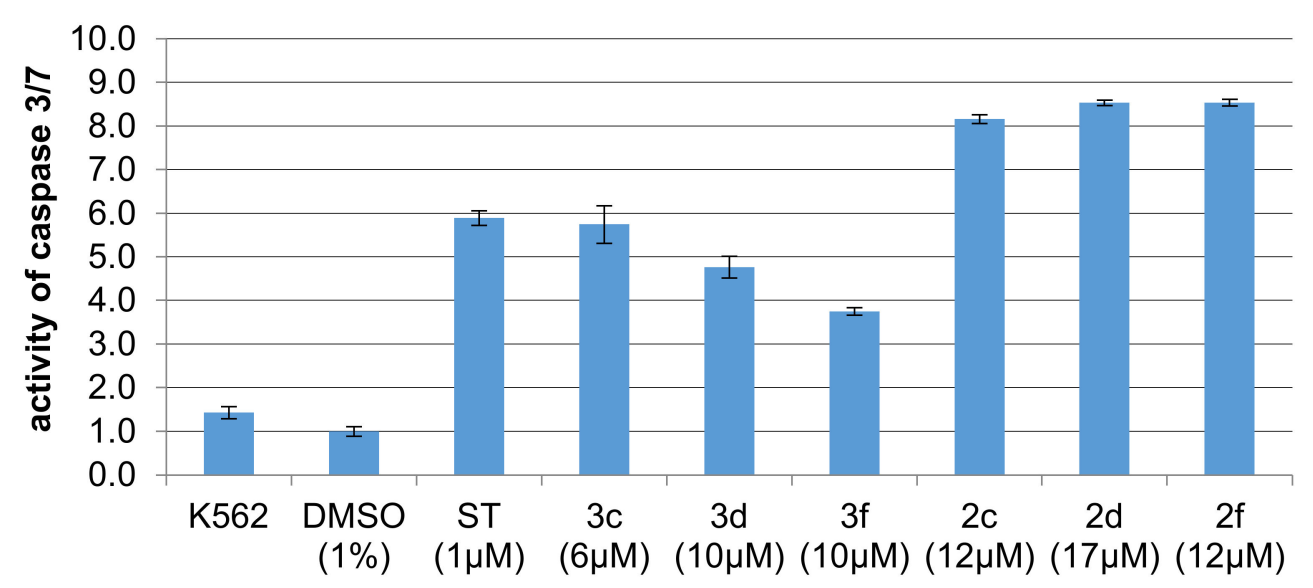

Figure 2. Activity of caspase $3 / 7$ in K562 cells treated with the test dicarboximides or staurosporine for $18 \mathrm{~h}$. Abbreviations: K562-untreated cells; DMSO-K562 cells treated with 1\% DMSO; ST—staurosporine. The activity of caspase 3/7 in cells exposed to $1 \%$ DMSO was normalized to 1.0. Mean values \pm SD are shown. 
We also profiled the expression of 93 genes associated with apoptosis in leukemia cells treated with the lead dicarboximide Ic. We showed previously that compound Ic induced apoptosis in CML K562 cells and acute lymphoblastic leukemia (ALL) cells MOLT-4, and that both receptor-mediated and mitochondrial apoptotic pathways may be involved [9,11]. K562 leukemia cells were incubated for $18 \mathrm{~h}$ with $1 \%$ DMSO (controlcomparator), staurosporine $(1 \mu \mathrm{M}$, positive control), or compound Ic $(10 \mu \mathrm{M})$. Subsequently, the total RNA was isolated and the expression of $93 \mathrm{mRNAs}$ associated with apoptosis was determined using DNA microarrays. The expression profile of apoptotic genes upon treatment with Ic was similar to staurosporine, a known proapoptotic agent (Figure 3 and Supplementary Materials Table S1). The expression of 12 genes was significantly upregulated in response to Ic (Figure 3).

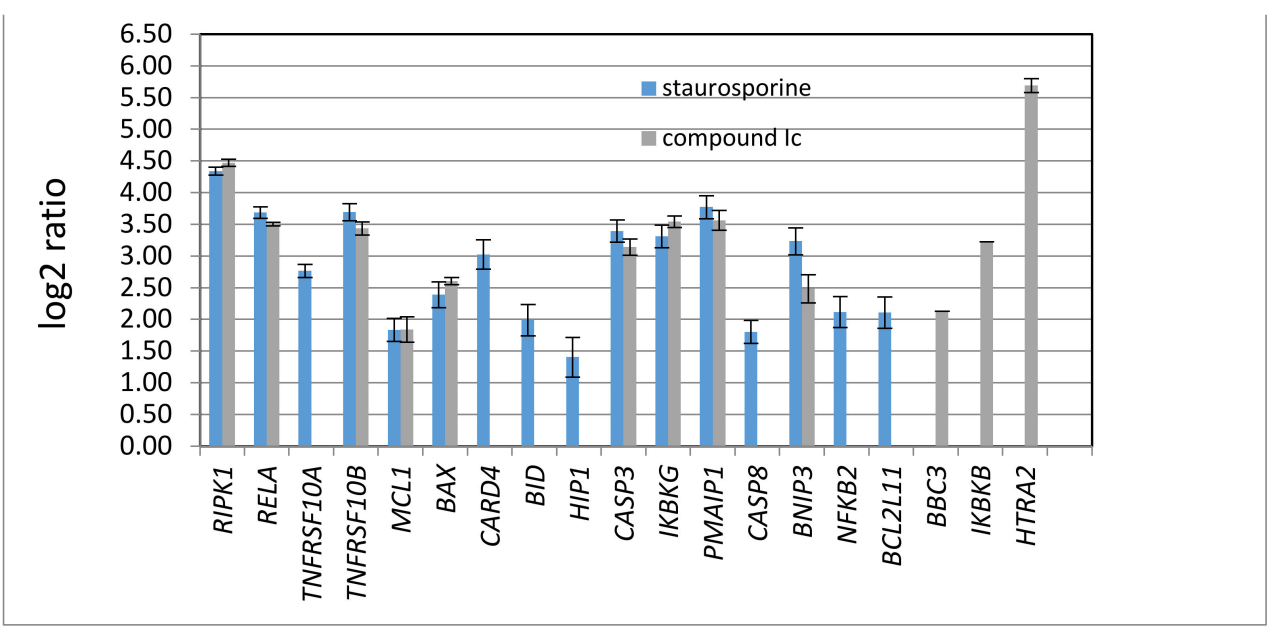

Figure 3. Human apoptosis array analysis of gene expression in K562 exposed to compound Ic at $10 \mu \mathrm{M}$ $\left(5 \times \mathrm{IC}_{50}\right)$ for $18 \mathrm{~h}$. Staurosporine $(1 \mu \mathrm{M})$ served as a positive control. Only apoptosis-related genes with statistically significant changes in expression are shown ( $p<0.05, t$-Student). The fold of change was expressed as $\log 2$ ratio of gene expression in a test sample vs control sample (cells + DMSO).

Eight of these genes encode proteins with proapoptotic activity. For example, TNFRSF10B (a membrane receptor from the TNF family) and RIPK1 (a Ser-Thr kinase, which is a key regulator of TNF-mediated apoptosis) activate the receptor pathway of apoptosis. PMAIP1 (Phorbol-12-Myristate-13-Acetate-Induced Protein 1), BAX (BCL2 Associated $\mathrm{X}$, a Bcl-2 family member), BBC3 (BCL2 Binding Component 3, a Bcl-2 family member), and BNIP3 (BCL2 Interacting Protein 3) induce apoptosis via the mitochondrial pathway. HTRA2 (HtrA Serine Peptidase 2) promotes apoptosis by binding and inhibiting IAPs (inhibitor of apoptosis proteins), while CASP3 (caspase 3) is a major executioner protease during cell apoptosis. Only one of the upregulated genes encodes a protein that inhibits apoptosis, i.e., MCL1 (Myeloid Cell Leukemia Sequence 1), which belongs to the Bcl-2 family. Interestingly, compound Ic also increased the expression of genes that encode antiapoptotic proteins involved in the activation of the transcription factor NF-kB. Specifically, IKBKB (Inhibitor Of Nuclear Factor Kappa B Kinase Subunit Beta) and IKBKG (Inhibitor Of Nuclear Factor Kappa B Kinase Subunit Gamma) are protein kinases that activate NF-kB in cells, and RelA is a subunit of NF-kB heterodimer.

\subsection{Effect of Dicarboximides on MAP Kinase Signaling Pathways}

In this study, we have demonstrated that new derivatives of dicarboximides are cytotoxic and induce apoptosis in leukemia cells. Similar effects were observed for previously studied lead compounds Ic and II [9,11]; therefore, we investigated whether mitogenactivated protein kinases (MAPKs) were involved in mediating dicarboximides-induced cytotoxic effects and induction of apoptosis. MAPKs include extracellular signal-regulated kinases (ERK1/2), p38 kinase, and c-Jun N-terminal kinase (JNK), which regulate cellular 
responses to multiple stimuli like growth factors, cytokines, stress signals, or cytotoxic drugs. In cells exposed to stress conditions (for example toxic compounds), p38 kinase and JNK kinase are often activated, leading to cell cycle arrest and apoptosis. To investigate the effect of dicarboximides on MAPKs, leukemia cells were incubated with lead compounds Ic and II, and subsequently, cell lysates were immunoblotted with specific antibodies recognizing activated (i.e., phosphorylated) forms of MAP kinases. As positive controls, we used cells treated with staurosporine (activates ERK1/2) or anisomycin (activator of JNK and p38 kinases). As expected, the incubation of K562 cells with compounds Ic or II had no effect on the ERK pathway, which is usually activated by growth factors and promotes cell proliferation (Figure 4a). However, dicarboximides Ic and II activated JNK and p38 kinases. This is evidenced by increased phosphorylation of JNK and p38 kinase (Figure $4 \mathrm{~b}, \mathrm{c}$, lanes 3 and 4 ) compared to control (lane 1). These data suggest that in leukemia cells dicarboximides activate stress signaling pathways regulated by JNK and p38 kinases, which subsequently leads to apoptotic death.

(a)

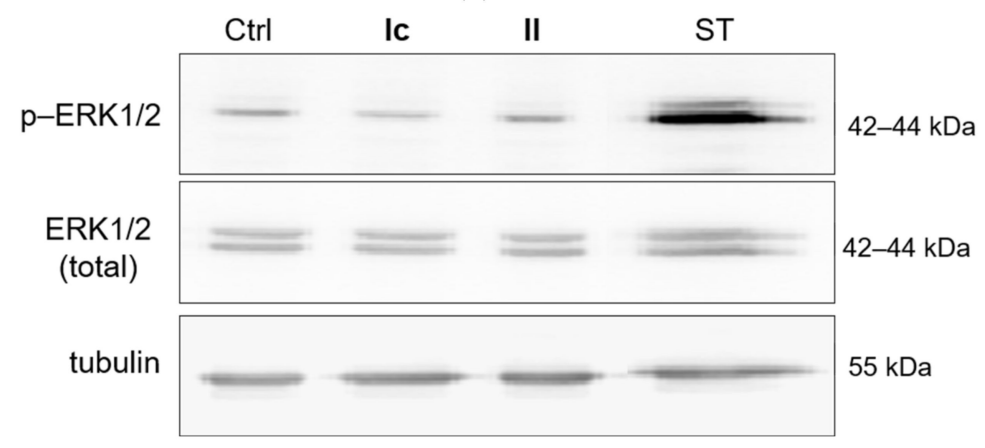

(b)

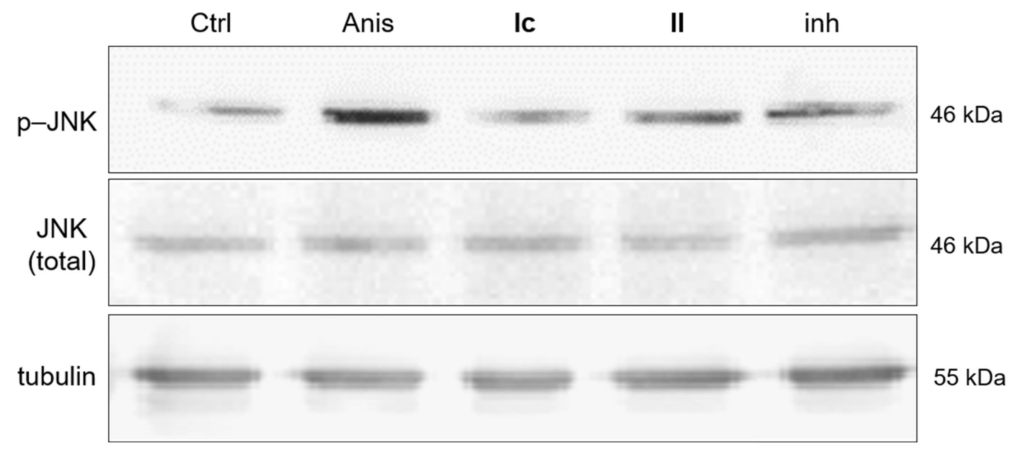

(c)

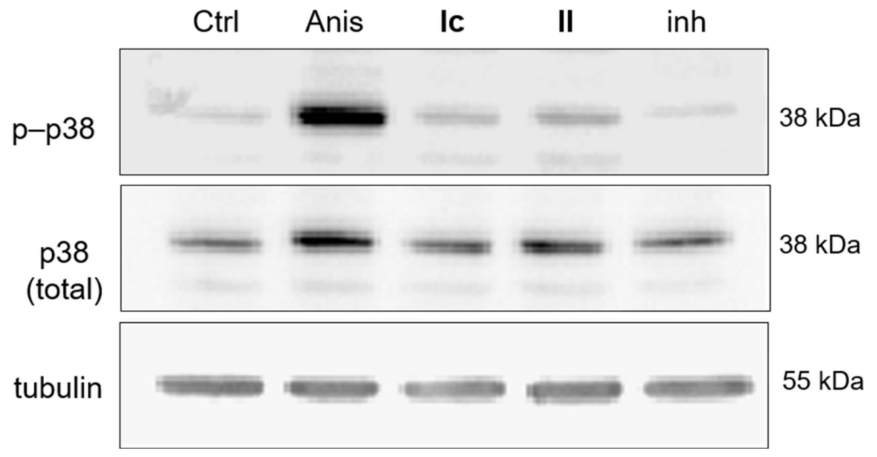

Figure 4. Effect of dicarboximides Ic and II on activation of ERK1/2 (a), JNK (b), and p38 (c) kinases in K562 leukemia cells. Ctrl—control cells treated with 1\% DMSO; Anisomycin $20 \mu \mathrm{M}$ (positive control, activator of JNK and p38 kinases); Ic $(6 \mu \mathrm{M})$; II $(3 \mu \mathrm{M})$; ST—Staurosporine $1 \mu \mathrm{M}$ (positive control, activator of ERK1/2); inh-JNK inhibitor $20 \mu \mathrm{M}$ or p38 inhibitor $10 \mu \mathrm{M}$. 


\subsection{Interaction with DNA}

A DNA-cleavage protection assay has been successfully used for the identification of compounds that bind DNA either covalently or noncovalently. Such binding may result in DNA being less susceptible to enzymatic cleavage [12]. Using this assay, we showed previously that compound Ic may interact with DNA [9,10]. It was also reported that naphtalenoimides or indolomaleimides intercalate into DNA $[13,14]$. With the aid of circular dichroism (CD) spectroscopy, we demonstrated the direct binding of Ic to DNA (Supplementary Materials Figure S1). In CD studies, a synthetic 23-nt duplex DNA or bovine thymus DNA was incubated with compound Ic or daunorubicin (reference compound). CD spectra indicated that compound Ic induced conformational changes in DNA compared to the control sample (Supplementary Materials Figure S1). This observation suggests that the cytotoxicity of dicarboximides may result from binding to and damaging the double-stranded DNA. Using a DNA-cleavage protection assay, we investigated whether selected compounds $\mathbf{2} \mathbf{c}, \mathbf{2} \mathbf{d}$, and $\mathbf{2 f}$ and $\mathbf{3 c}, \mathbf{3 d}$, and $\mathbf{3 f}$ interact with a plasmid DNA, resulting in increased resistance to endonucleolytic cleavage. Plasmid DNA (pcDNA3.1HisC) containing a single BamHI cleavage site was incubated with test compounds and subsequently digested with BamH1 restriction endonuclease. Daunorubicin (a strong DNA-intercalating agent) was used as a reference compound. Non-digested plasmid DNA existed predominantly in the circular form; however, the superhelical and linear forms were also detected (Figure 5, lane 1). Digestion with the BamH1 enzyme converted the plasmid into a linear form (Figure 5, lane 2; no circular DNA), while daunorubicin (at $100 \mu \mathrm{M})$ prevented linearization of DNA (Figure 5, lane 3; circular DNA present). In the presence of test dicarboximides, the linear plasmid DNA was predominant; however, the circular form was also detected (Figure 5 lane 4-9). This indicates that test dicarboximides interact with DNA. Interestingly, this interaction seems to be stronger for $\mathbf{3 c}, \mathbf{3 d}$, and $\mathbf{3 f}$ (as more circular DNA is observed in lanes 4-6) than for the remaining test compounds (lanes 7-9). This observation can be explained by the higher lipophilicity of $\mathbf{3 c}, \mathbf{3 d}$, and $\mathbf{3 f}$ compared to $\mathbf{2 c}, \mathbf{2} \mathbf{d}$, and $\mathbf{2 f}$, which may facilitate their more efficient binding to DNA.

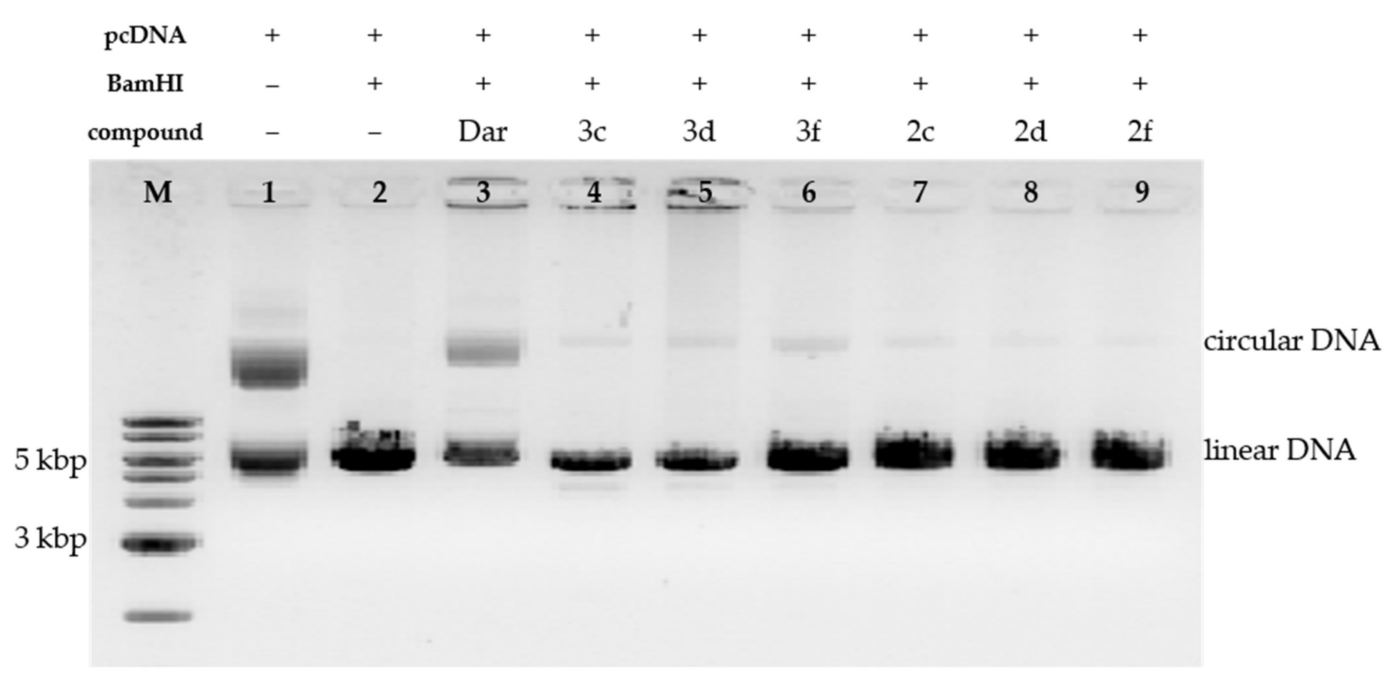

Figure 5. Effect of dicarboximides on digestion of pcDNA3.1HisC (total length $5.5 \mathrm{kbp}$ ) with BamH1 endonuclease observed by agarose gel electrophoresis. $\mathrm{M}$-marker DNA; Dar-daunorubicin.

\section{Discussion}

In our previous studies, we identified several derivatives of dicarboximides (Ia-Ie, II) that efficiently killed cancer cells and were not toxic to normal endothelial cells [9-11]. Compounds Ic, Ie, and II were particularly promising, as they showed specificity to cancer cells only and induced apoptosis. However, they are lipophilic (Table 1) and have limited water solubility. Based on their structures, we have designed and synthesized a library of 
26 new derivatives of dicarboximides with lower lipophilicity, which is a desired property for potential new drug candidates. This was achieved mainly by the replacement of ethyl groups in the imide scaffold by methyl groups at positions 1 and 7 as well as by the introduction of a side chain with the hydroxyalkyl group substituted with alkylamino groups (Scheme 1). This resulted in significantly lower lipophilicity of derivatives of imide 1 (median $\operatorname{cog} P$ 3.19), and imide 2 (median $\operatorname{cog} P$ of 4.1) compared to parent compounds Ia-Ie (median $\operatorname{cog} P$ 4.27). However, chemical modifications introduced to derivatives of imide 3 rather increased their lipophilicity (median $\log P 5.69$ ) when compared to the parent dicarboximide II $(\operatorname{cog} P 5.45)$ (Table 1). Lipophilicity is the most important property of new drug candidates. According to Lipinski's rule, $\operatorname{cog} P>5$ predicts poor absorption and/or permeability of a drug [15]. In addition, high lipophilicity may increase the unspecific cytotoxicity [16].

The cytotoxic properties of all investigated analogs were tested in human cells of cancer and normal origin. Fourteen compounds $\left(\mathbf{1 b}, \mathbf{1 e}, \mathbf{2 b}-\mathbf{2 f}, \mathbf{3} \mathbf{c}-\mathbf{3 g}, \mathbf{5}, \mathbf{I e}^{*}\right)$ displayed significant cytotoxicity toward cancer cell lines $\left(\mathrm{IC}_{50}<10 \mu \mathrm{M}\right)$; however, they were less toxic than the lead compounds and exhibited cytotoxicity in normal endothelial cells (Table 2). Comparison of $\mathrm{IC}_{50}$ values indicates that compounds with lower lipophilicity are less cytotoxic. This is particularly evident for derivatives of dicarboximid $\mathbf{1}$, which show the lowest cytotoxicity.

Preliminary studies on derivatives $\mathbf{3 c}, \mathbf{3 d}, \mathbf{3 f}, \mathbf{2 c}, \mathbf{2 d}$, and $\mathbf{2 f}$ showed that these compounds activated caspase 3 and 7 in K562 cells (Figure 2). This suggests that the cytotoxicity of the new derivatives is associated with the induction of apoptosis in CML cells. Interestingly, proapoptotic activity of dicarboximides seems to depend on lipophilicity. Derivatives of imide $\mathbf{2}$ (median $\operatorname{clog} P 4.1$ ) were significantly more potent than derivatives of imide $\mathbf{3}$ (me$\operatorname{dian} \operatorname{cog} P$ 5.69). Apoptosis may proceed through two major pathways: receptor-mediated (extrinsic) and mitochondrial (intrinsic) [17]. The effect of dicarboximides on apoptotic pathways was investigated by microarray-based gene expression profiling. We found that several pro-apoptotic genes involved in the receptor and mitochondrial apoptotic pathways were upregulated in K562 cells treated with Ic. The expression profile induced by Ic was similar to staurosporine, a natural compound that activates mainly the mitochondrial pathway of apoptosis [18]. Specifically, compound Ic upregulated the expression of TNFRSF10B and RIPK1, which promote apoptosis via the receptor (extrinsic) pathway. TNFRSF10B belongs to a TNF family of transmembrane receptors. Upon binding the TRAIL ligand (TNF-related apoptosis-inducing ligand), TNFRSF10B is activated leading to caspase 8-mediated apoptosis [19]. Interestingly, in response to cytotoxic agents cancer cells overexpress TNFRSF10B, and this seems to be sufficient to trigger ligand-independent apoptosis [20]. RIPK1 (Receptor Interacting Serine/Threonine Kinase 1) is involved in signaling events downstream of TNFR1 that (depending on the cellular context) may lead to apoptosis through recruitment of FADD and subsequent activation of caspase 8 [21] or promote necroptosis through phosphorylation of RIPK3 and MLKL [22]. Compound Ic also increased the expression of protein genes involved in the mitochondrial (intrinsic) pathway of apoptosis: PMAIP1 (Phorbol-12-Myristate-13-Acetate-Induced Protein 1), BAX (BCL2 Associated X, a Bcl-2 family member), $B B C 3$ (BCL2 Binding Component 3, a Bcl-2 family member), and BNIP3 (BCL2 Interacting Protein 3). BAX is a member of the Bcl-2 family of proteins and a key activator of the intrinsic apoptotic pathway. In response to cellular stress, $\mathrm{BAX}$ is activated and oligomerizes, forming pores in the mitochondrial outer membrane. This enables cytochrome $\mathrm{c}$ and/or SMAC/Diablo proteins to leak into the cytoplasm and activate caspase 3 [23]. BBC3 is a pro-apoptotic protein that belongs to a class of BH3-only proteins. BBC3 binds other anti-apoptotic Bcl2 proteins (for example antiapoptotic MCL1) using its $\mathrm{BH} 3$ domains and thus promotes apoptosis. Interestingly, the expression of $\mathrm{BBC} 3$ is induced by DNA damaging agents and regulated by p53 [24]. This could explain the increased expression of BBC 3 in K562 cells treated with Ic, as we demonstrated previously that this compound interacts with DNA and thus may be considered a DNA-damaging agent [9]. Altogether, these results suggest that dicarboximides activate both receptor- 
mediated and mitochondrial pathways of apoptosis by the upregulation of several genes involved in both pathways.

Interestingly, compound Ic also increased the expression of anti-apoptotic genes encoding IKBKB /IKK $\beta$ (Inhibitor Of Nuclear Factor Kappa B Kinase Subunit Beta), IKBKG/IKK $\gamma$ (Inhibitor Of Nuclear Factor Kappa B Kinase Subunit Gamma), and RelA, which serves as a subunit of NF- $\mathrm{KB}$ heterodimer. These proteins are involved in the activation and function of transcription factor NF- $\mathrm{kB}$, which regulates the expression of several genes involved in inflammation, immune responses, cell survival, and tumorigenesis and inhibits apoptosis. Serine kinase IKK $\beta$ and regulatory protein Ikk $\gamma$ are key components of the IKK complex, which is essential for the activation of NF- $\mathrm{KB}$ transcription factors. The anti-apoptotic activity of IKK $\beta$ and IKK $\gamma$ has been confirmed in studies using knockout mice. IKK $\beta$-deficient mice died during embryonic development due to the uncontrolled apoptosis of liver cells [25]. A similar phenotype, i.e., liver apoptosis was observed in the case of Ikk $\gamma$-deficient male embryos, leading to their death on day (E)12 [26].

The cytotoxic effects of dicarboximides may also be mediated by MAPKs, a family of Ser-Thr kinases that consists of ERK1/2, p38, and JNK kinase. We demonstrated that in cells exposed to lead dicarboximides Ic and II, p38 and JNK kinases are activated while there was no effect on ERK1/2 (Figure 4). ERK1/2 are activated mainly by growth factors (for example PDGF or EGF) and positively control cell proliferation by promoting G1- to S-phase transition [27]. On the other hand, p38 and JNK kinases are activated by stress conditions, for example, oxidative stress, ionizing radiation, cytotoxic/genotoxic agents, DNA damage, inflammatory cytokines, or deprivation of growth factors. In response to stress conditions, JNK transactivates the c-Jun transcription factor or phosphorylates proteins associated with apoptosis, leading to activation of both mitochondrial and receptormediated pathways of apoptosis [28]. Similarly, activation of p38 leads to inhibition of cell cycle progression and induction of apoptosis [29,30]. Our results suggest that p38 and JNK can contribute to the activation of apoptosis induced by Ic and II.

We also examined whether DNA may be targeted by test derivatives. The obtained results showed that dicarboximides inhibited the digestion of plasmid DNA with BamHI endonuclease, albeit to a lower extent than daunorubicin (Figure 5). These data suggest that the test dicarboximides may intercalate to DNA and possibly cause DNA damage. This property of dicarboximides (including compound Ic) could explain the increased expression of the BBC3 gene in K562 cells exposed to Ic, as discussed above.

The SAR analysis indicated that the volume of substituents at positions 1 and 7 of the imide system is an important factor in determining the cytotoxicity of dicarboximides (Figure 1). This conclusion is supported by comparison of the cytotoxic and apoptotic activities in three sets of compounds: $\mathbf{1 c}$, $\mathbf{2 c}$, and $\mathbf{3 c}$; $\mathbf{1 d}, \mathbf{2 d}$, and $\mathbf{3 d}$; or $\mathbf{1 f}, \mathbf{2 f}$, and $\mathbf{3 f}$. The derivatives containing ethyl or phenyl groups at positions 1 and 7 showed lower $\mathrm{IC}_{50}$ towards HeLa, K456, and MOLT-1 cells than compounds with methyl groups. The type of alkylamine substituent in the side chain is also important for inducing cytotoxicity and apoptosis-signaling pathways. Dicarboximides with alkylamine substituent bearing a protonated nitrogen atom at physiological $\mathrm{pH}$ (pKa of amines is $>9.0,[31]$ ) were the most active. For example, tert-butyl derivatives ( $2 \mathrm{c}$ and $3 \mathrm{c}$ ), piperidynyl derivatives ( $2 \mathrm{f}$ and 3f), dibutyl derivatives (1e, 2e, and 3e), and diethylamine derivative (3d) showed the highest cytotoxicity against cancer cells tested. It is worth noting that all of the abovementioned compounds have values of $\operatorname{cog} P>4$. On the other hand, compounds containing the morpholine system i.e., $\mathbf{1 g}$, $\mathbf{2} \mathbf{g}$, and $\mathbf{3 g}$ (with the lowest $\operatorname{cog} P$ values among other derivatives within the corresponding group of imides 1,2 , and 3 , respectively) exhibited the lowest cytotoxicity towards tested cell lines. This result suggests that the presence of an acceptor oxygen atom at the morpholine ring, but not the cyclic structure of the substituent, is responsible for undesirable interactions that are not offered by the piperidine ring of $\mathbf{1 f}, \mathbf{2 f}$, and $\mathbf{3 f}$. The favorable role of the protonated nitrogen atom of the alkylamino group is further supported by comparison of compounds of scaffold $\mathbf{1}$, which are less or not cytotoxic when the imide function is substituted with hydroxyalkyl (4) or chloroethyl 
substituent (1h), respectively, but exhibit higher cytotoxicity when $\mathbf{1 h}$ is substituted with a tert-butyl amine residue (1i). However, the presence of the protonated alkylamino group is not an obligatory feature to provide high cytotoxicity, since, e.g., compound $\mathbf{5}$, containing a hydroxyalkyl side chain, exhibited significant cytotoxicity. The activity of the lead compounds is also influenced by the type of salts, i.e., acetate vs. hydrochloride. The acetate salts showed lower cytotoxicity and lacked selectivity against the studied cell lines. It can be hypothesized that the change of polarization of the molecule by the acetate anion and the decrease in the hydrophilicity could affect the activity of these derivatives.

\section{Materials and Methods}

\subsection{Chemistry}

All chemicals used in the reaction were supplied from Sigma-Aldrich (Saint Louis, MO, USA) or POCH (Polskie Odczynniki Chemiczne, Gliwice, Poland). Melting points were determined by the capillary method using the Electrothermal 9100 apparatus and were uncorrected. The nuclear magnetic resonance spectra were recorded in DMSO- $\mathrm{d}_{6}$ or $\mathrm{CDCl}_{3}$ on VMNRS300 spectrometer (Bruker, Billerica MA, USA) operating at $300 \mathrm{MHz}$ $\left({ }^{1} \mathrm{HNMR}\right)$ and $75 \mathrm{MHz}\left({ }^{13} \mathrm{CNMR}\right)$. Chemical shifts $(\delta)$ are expressed in parts per million relative to tetramethylsilane (TMS) used as the internal reference. Coupling constants $(J)$ values are given in hertz $(\mathrm{Hz})$, and spin multiples are given as s (singlet), $\mathrm{d}$ (doublet), $\mathrm{t}$ (triplet), and $\mathrm{m}$ (multiplet). Mass spectral ESI (electrospray ionization) measurements were carried out on a MicrOTOF II Bruker instrument with a TOF detector. The spectra were obtained in the positive ion mode. Flash chromatography was performed on Merck Kieselgel (Darmstadt, Germany) 0.05-0.2 mm reinst (70-325 mesh ASTM) silica gel using chloroform or chloroform-methanol as an eluent system at the $v / v$ ratio of 50:0.2 or 50:0.5. The progress of the reactions described in the experimental section was monitored by TLC on silica gel (plates with fluorescent indicator $254 \mathrm{~nm}$, layer thickness $0.2 \mathrm{~mm}$, Kieselgel G. Merck), using chloroform-methanol as an eluent system at the $v / v$ ratio of 9.8:0.2 or 9.5:05.

\subsubsection{Synthesis of Imides $\mathbf{1}-\mathbf{5}$ and $\mathbf{1 h}$}

The starting imides $\mathbf{1 - 3}$ were prepared by the methods described earlier [10,32].

4.1.2. Synthesis of 1,7-Dimethyl-8,9-diphenyl-4-azatricyclo[5.2.1.0 2,6]dec-8-ene-3,5,10trione (1)

A mixture of 2,5-dimethyl-3,4-diphenylcyclopenta-2,4-dien-1-one (0.02 mol) and maleimide $(0.022 \mathrm{~mol})$ was heated for $6 \mathrm{~h}$ in $20 \mathrm{~mL}$ of benzene. During the synthesis, the solution became red, and a white solid precipitated from it. When the reaction was completed, the solvent was evaporated under reduced pressure, and the solid residue was crystallized from benzene.

M.W. $=357.4018 ; \mathrm{C}_{23} \mathrm{H}_{19} \mathrm{NO}_{3}$; Yield: $77 \%$, white powder, m.p. $220.6-221.1{ }^{\circ} \mathrm{C}$ (from benzen); ${ }^{1} \mathrm{HNMR}\left(300 \mathrm{MHz}, \mathrm{DMSO}-\mathrm{d}_{6}+\mathrm{TMS}, \delta / \mathrm{ppm}\right): 1.39\left(6 \mathrm{H}, \mathrm{s},-\mathrm{CH}_{3}\right) ; 3.38(2 \mathrm{H}, \mathrm{s}$, C2-H, C6-H); 6.98 (4H, m, Ar-H); 7.19 (6H, m, Ar-H); 11.66 (1H, s, NH); Anal. Calc for $\mathrm{C}_{23} \mathrm{H}_{19} \mathrm{~N}_{3} \mathrm{O}_{3}: 77.28 \% \mathrm{C} ; 5.32 \% \mathrm{H}, 3.92 \% \mathrm{~N}$; found $77.40 \% \mathrm{C} ; 5.30 \% \mathrm{H} ; 3.99 \% \mathrm{~N} ;{ }^{13} \mathrm{CNMR}$ : $\delta$ 11.7, 48.5, 55.5, 127.4, 127.9, 129.4, 133.2, 141.3, 177.5, 199.5; HRMS $(\mathrm{m} / \mathrm{z})$ : calculated value for $\left[\mathrm{M}+\mathrm{Na}^{+}\right] 380.1257$; found 380.1259 .

4.1.3. Synthesis of 1,7-Diethyl-8,9-tetraphenyl-4-azatricyclo[5.2.1.0 $\left.{ }^{2,6}\right]$ dec-8-ene-3,5,10trione (2)

A mixture of 2,5-diethyl-3,4-diphenylcyclopenta-2,4-dien-1-one ( $0.01 \mathrm{~mol})$ and maleimide $(0.012 \mathrm{~mol})$ in benzene $(15 \mathrm{~mL})$ was refluxed for $14 \mathrm{~h}$. When the reaction was completed, the solvent was evaporated under reduced pressure, and the solid residue was crystallized from benzene.

M.W. $=385.455 ; \mathrm{C}_{25} \mathrm{H}_{23} \mathrm{NO}_{3}$; Yield: $92 \%$; white powder, m.p. $206.8-209^{\circ} \mathrm{C}$ (from benzen); ${ }^{1} \mathrm{HNMR}\left(300 \mathrm{MHz}, \mathrm{DMSO}-\mathrm{d}_{6}+\mathrm{TMS}, \delta / \mathrm{ppm}\right): 0.87\left(6 \mathrm{H}, t, J=7.5 \mathrm{~Hz},-\mathrm{CH}_{3}\right) ; 2.05(\mathrm{~m}, 4 \mathrm{H}$, $\left.-\mathrm{CH}_{2}-\right), 3.58(2 \mathrm{H}, \mathrm{s}, \mathrm{C} 2-\mathrm{H}, \mathrm{C} 6-\mathrm{H}) ; 6.97(4 \mathrm{H}, m, \mathrm{Ar}-\mathrm{H}) ; 7.18(6 \mathrm{H}, m, \mathrm{Ar}-\mathrm{H}) ; 11.70(1 \mathrm{H}, \mathrm{s}, \mathrm{NH})$; 
Anal. Calc for $\mathrm{C}_{25} \mathrm{H}_{23} \mathrm{NO}_{3}$ : 77.93\% C; $5.98 \% \mathrm{H}, 3.63 \% \mathrm{~N}$; found $77.94 \% \mathrm{C} ; 5.97 \% \mathrm{H} ; 3.62 \%$ $\mathrm{N} ;{ }^{13} \mathrm{CNMR}$ : $\delta$ 9.1, 19.2, 43.9, 55.3, 60.4, 128.0, 129.4, 133.1, 142.4, 171.6, 197.8; HRMS (m/z): calculated value for $\left[\mathrm{M}+\mathrm{Na}^{+}\right]$408.1570; found 408.1570 .

4.1.4. Synthesis of 1,7,8,9-Tetraphenyl-4-azatricyclo[5.2.1.0 $\left.0^{2,6}\right]$ dec-8-ene-3,5-dione (3)

A mixture of 1,2,3,4-tetraphenylcyclopenta-1,3-diene ( $0.02 \mathrm{~mol})$ and maleimide $(0.022 \mathrm{~mol})$ was heated for $6 \mathrm{~h}$ in $20 \mathrm{~mL}$ of benzene. When the reaction was completed, the solvent was evaporated under reduced pressure, and the solid residue was crystallized from benzene.

M.W. $=467.5571 ; \mathrm{C}_{33} \mathrm{H}_{25} \mathrm{NO}_{2} ;$ Yield: 81\%, white powder, m.p. 246.5-246.9 ${ }^{\circ} \mathrm{C}$ (from benzen); ${ }^{1} \mathrm{HNMR}$ (300 MHz, DMSO-d $\left.6+\mathrm{TMS}, \delta / \mathrm{ppm}\right): 2.23(1 \mathrm{H}, d, J=8.4, \mathrm{C} 10-\mathrm{H}), 3.23$ $(1 \mathrm{H}, d, J=8.7, \mathrm{C} 10-\mathrm{H}), 4.20(2 \mathrm{H}, s, \mathrm{C} 2-\mathrm{H}, \mathrm{C} 6-\mathrm{H}) ; 6.60(4 \mathrm{H}, m, \mathrm{Ar}-\mathrm{H}) ; 6.88(6 \mathrm{H}, m, \mathrm{Ar}-\mathrm{H})$; $7.24(6 \mathrm{H}, m, \mathrm{Ar}-\mathrm{H}) ; 7.74(4 \mathrm{H}, d, J=7.2, \mathrm{Ar}-\mathrm{H}) ; 11.44(1 \mathrm{H}, s, \mathrm{NH})$; Anal. Calc for $\mathrm{C}_{33} \mathrm{H}_{25} \mathrm{NO}_{2}$ : $84.79 \%$ C; $5.35 \% \mathrm{H}, 3.00 \% \mathrm{~N}$; found $84.85 \% \mathrm{C} ; 5.39 \% \mathrm{H} ; 3.08 \% \mathrm{~N} ;{ }^{13} \mathrm{CNMR}: \delta 52.9,62.9,65.1$, $126.4,126.6,127.1,127.7,129.1,129.6,134.5,139.8,145.0,178.0 ; \operatorname{HRMS}(m / z)$ : calculated value for $\left[\mathrm{M}+\mathrm{Na}^{+}\right] 490.1778$; found 490.1777 .

\subsubsection{Synthesis of N-Hydroxyethylimides 4 and 5}

A mixture of an appropriate diene:

- 2,5-dimethyl-3,4-diphenylcyclopenta-2,4-dien-1-one (0.02 mol) for compound 4 - 1,2,3,4-tetraphenylcyclopenta-1,3-diene $(0.02 \mathrm{~mol})$ for compound 5 and $\mathrm{N}$-hydroxymaleimide $(0.022 \mathrm{~mol})$ was heated for $6 \mathrm{~h}$ in $20 \mathrm{~mL}$ of benzene. When the reaction was completed, the solvent was evaporated under reduced pressure, and the solid residue was crystallized from benzene.

4-(2-hydroxyethyl)-1,7-dimethyl-8,9-diphenyl-4-azatricyclo[5.2.1.0 2,6]dec-8-ene-3,5,10trione (4)

M.W. $=401.4544 ; \mathrm{C}_{25} \mathrm{H}_{23} \mathrm{NO}_{4}$; Yield: 84\%; white powder, m.p. $186-187^{\circ} \mathrm{C}$ (from MeOH/ $\left.(\mathrm{Et})_{2} \mathrm{O}\right) ;{ }^{1} \mathrm{HNMR}\left(300 \mathrm{MHz}, \mathrm{DMSO}-\mathrm{d}_{6}+\mathrm{TMS}, \delta / \mathrm{ppm}\right): 1.57\left(6 \mathrm{H}, \mathrm{s},-\mathrm{CH}_{3}\right), 2.16(1 \mathrm{H}, \mathrm{s},-\mathrm{OH})$, 3.25 (2H, m, C2-H, C6-H), $3.73\left(4 \mathrm{H}, m,-\mathrm{CH}_{2}-\right), 6.93(4 \mathrm{H}, m, \mathrm{Ar}-\mathrm{H}), 7.26$ (6H, m, Ar-H); ${ }^{13}$ CNMR: $\delta$ 12.2, 47.4, 47.9, 56.5, 60.1, 127.7, 128.1, 129.4, 132.9, 141.5, 175.8, 176.1, 199.3; $\operatorname{HRMS}(m / z)$ : calculated value for $\left[\mathrm{M}+\mathrm{Na}^{+}\right] 424.1519$; found 424.1519 .

4-(2-hydroxyethyl)-1,7,8,9-tetraphenyl-4-azatricyclo[5.2.1.02,6]dec-8-ene-3,5-dione (5)

M.W. = 511.6096; $\mathrm{C}_{35} \mathrm{H}_{29} \mathrm{NO}$; Yield: 61\%, white powder, m.p. 197-198 ${ }^{\circ} \mathrm{C}$ (from benzen); ${ }^{1} \mathrm{HNMR}\left(300 \mathrm{MHz}, \mathrm{DMSO}-\mathrm{d}_{6}+\mathrm{TMS}, \delta / \mathrm{ppm}\right): 2.12(1 \mathrm{H}$, br.s, $-\mathrm{OH}), 2.32(1 \mathrm{H}, d, J=4.5$, C6-H), $3.17(1 \mathrm{H}, d, J=4.5, \mathrm{C} 2-\mathrm{H}), 3.74\left(2 \mathrm{H}, m, \mathrm{C}^{\prime}-\mathrm{H}, \mathrm{C} 2^{\prime}-\mathrm{H}\right) ; 4.17(2 \mathrm{H}, \mathrm{s}, \mathrm{C} 10-\mathrm{H}), 6.55(4 \mathrm{H}$, $m, \mathrm{Ar}-\mathrm{H}) ; 6.89$ (6H, $m, \mathrm{Ar}-\mathrm{H}) ; 7.32(6 \mathrm{H}, m, \mathrm{Ar}-\mathrm{H}) ; 7.70(4 \mathrm{H}, m, \mathrm{Ar}-\mathrm{H}) ;{ }^{3} \mathrm{CNMR}: \delta 42.2,52.2$, $60.5,63.6,65.9,126.8,127.1,127.4,128.1,129.0,129.8,133.8,139.2,145.0,177.1$; HRMS (m/z): calculated value for $\left[\mathrm{M}+\mathrm{Na}^{+}\right] 543.5988$; found 534.2045 .

4.1.6. Synthesis of 4-(2-Chloroethyl)-1,7-dimethyl-8,9-diphenyl-4-azatricyclo[5.2.1.0 $\left.0^{2,6}\right]$ dec-8-ene-3,5,10-trione (1h)

To the solution of imide a $(0.01 \mathrm{~mol})$ in acetonitrile $(30 \mathrm{~mL}), 1,2$-dichloroethane $(0.02 \mathrm{~mol})$ was added. The reaction was heated for $72 \mathrm{~h}$. When the reaction was completed, the solvent was evaporated under reduced pressure, and the residue was purified by column chromatography on silica gel (eluent: chloroform).

4-(2-chloroethyl)-1,7-dimethyl-8,9-diphenyl-4-azatricyclo[5.2.1.0 $\left.{ }^{2,6}\right]$ dec-8-ene-3,5,10trione (1h)

M.W. $=419.9000 ; \mathrm{C}_{25} \mathrm{H}_{22} \mathrm{ClNO}_{3}$; Yield: 74\%; white powder, m.p. $190-191{ }^{\circ} \mathrm{C}$ (from hexane); ${ }^{1} \mathrm{HNMR}\left(300 \mathrm{MHz}, \mathrm{CDCl}_{3}, \delta / \mathrm{ppm}\right): 1.58\left(6 \mathrm{H},-\mathrm{CH}_{3}\right), 3.28(2 \mathrm{H}, m, \mathrm{C} 2-\mathrm{H}, \mathrm{C} 6-\mathrm{H}), 3.64(2 \mathrm{H}$, $\left.t, J=6.4 \mathrm{~Hz}, \mathrm{C} 1^{\prime}-\mathrm{H},\right), 3.86\left(2 \mathrm{H}, t, J=6 \mathrm{~Hz}, \mathrm{C} 2^{\prime}-\mathrm{H}\right), 6.91(4 \mathrm{H}, m, \mathrm{Ar}-\mathrm{H}), 7.25(6 \mathrm{H}, m, \mathrm{Ar}-\mathrm{H})$; ${ }^{13}$ CNMR: $\delta 12.2,39.5,40.4,47.9,56.5,127.7,128,1,129.4,132.9,141.5,175.1,199.2 ;$ HRMS $(m / z)$ : calculated value for $\left[\mathrm{M}+\mathrm{Na}^{+}\right] 442.8893$; found 442.1175 . 
4.1.7. General Conditions of Synthesis of New N-Alkylamino Derivatives of 1,7-Dimethyl8,9-diphenyl-4-azatricyclo[5.2.1.0 ${ }^{2,6}$ ]dec-8-ene-3,5,10-trione (1i-1 $\left.\mathbf{j}\right)$

The 4-(2-chloroethyl)-1,7-dimethyl-8,9-diphenyl-4-azatricyclo[5.2.1.02,6]dec-8-ene-3,5,10trione was dissolved in acetonitrile $(30 \mathrm{~mL})$, and then anhydrous $\mathrm{K}_{2} \mathrm{CO}_{3}(0.01 \mathrm{~mol})$ and an appropriate amine $(0.01 \mathrm{~mol})$ were added. The reaction was carried out in reflux, respectively, for $24-48 \mathrm{~h}$ in the boiling temperature of the solvent. The reaction was monitored by TLC. When the reaction was completed, the solvent was evaporated, and the residue was purified by column chromatography on silica gel (eluent: chloroform or chloroform/methanol 50:0.2 $v / v)$.

4-[2-(morpholin-4-yl)ethy]-1,7-dimethyl-8,9-diphenyl-4-azatricyclo[5.2.1.0 $\left.{ }^{2,6}\right]$ dec-8-ene3,5,10-trione (1j)

M.W. $=470.5595$ (free amine); $\mathrm{C}_{29} \mathrm{H}_{30} \mathrm{~N}_{2} \mathrm{O}_{4}{ }^{*} \mathrm{HCl}$; Yield: 70\%; white powder, m.p. 227$228{ }^{\circ} \mathrm{C}$ (from EtOH/(Et) $\left.{ }_{2} \mathrm{O}\right) ;{ }^{1} \mathrm{HNMR}\left(300 \mathrm{MHz}, \mathrm{DMSO}-\mathrm{d}_{6}+\mathrm{TMS}, \delta / \mathrm{ppm}\right): 1.41(6 \mathrm{H}, \mathrm{s}$, $\left.-\mathrm{CH}_{3}\right), 3.09\left(2 \mathrm{H}, m,-\mathrm{CH}_{2}\right.$-morph), $3.30\left(2 \mathrm{H}, m,-\mathrm{CH}_{2}-\mathrm{morph}\right), 3.39$ (3H, $\left.m, \mathrm{C} 2-\mathrm{H}, \mathrm{C} 6-\mathrm{H}\right)$, $3.86\left(4 \mathrm{H}, m, \mathrm{C}^{\prime}-\mathrm{H},-\mathrm{CH}_{2}-\mathrm{morph}\right), 3.91\left(2 \mathrm{H}, m, \mathrm{C}^{\prime}-\mathrm{H}\right), 6.87(4 \mathrm{H}, m, \mathrm{Ar}-\mathrm{H}), 7.18(6 \mathrm{H}, m$, Ar-H), 11.57 (1H, br.s, $\left.\mathrm{NH}^{+}\right)$; ${ }^{13} \mathrm{CNMR}: \delta 11.8,32.5,48.1,50.9,52.3,55.6,62.8,127.5,128,1$, 129.2, 133.1, 141.4, 176.3, 199.2; HRMS $(m / z)$ : calculated value for $\left[\mathrm{M}+\mathrm{H}^{+}\right]$471.2278; found 471.2276 .

4-[2-(piperidin-1-yl)ethy]-1,7-dimethyl-8,9-diphenyl-4-azatricyclo[5.2.1.0 2,6]dec-8-ene3,5,10-trione (1i)

M.W. $=468.5866$ (free amine); $\mathrm{C}_{30} \mathrm{H}_{32} \mathrm{~N}_{2} \mathrm{O}_{3}{ }^{*} \mathrm{HCl}$; Yield: $64 \%$; white powder, m.p. $214-$ $216^{\circ} \mathrm{C}$ (from EtOH/ $\left.(\mathrm{Et})_{2} \mathrm{O}\right) ;{ }^{1} \mathrm{HNMR}\left(300 \mathrm{MHz}, \mathrm{CDCl}_{3}, \delta / \mathrm{ppm}\right): 1.42\left(6 \mathrm{H},-\mathrm{CH}_{3}\right), 1.76(4 \mathrm{H}$, $m$, - $\mathrm{CH}_{2}$-piper), $2.85\left(2 \mathrm{H}, m, \mathrm{C}^{\prime}-\mathrm{H}\right), 3.16\left(2 \mathrm{H}, m, \mathrm{C}^{\prime}-\mathrm{H}\right), 3.36(1 \mathrm{H}, m, \mathrm{C} 6-\mathrm{H}), 3.49(1 \mathrm{H}, m$, $\mathrm{C} 2-\mathrm{H}), 3.54\left(4 \mathrm{H}, m,-\mathrm{CH}_{2}\right.$-piper), $3.82\left(2 \mathrm{H}, m,-\mathrm{CH}_{2}\right.$-piper), $6.86(4 \mathrm{H}, m, \mathrm{Ar}-\mathrm{H}), 7.19(6 \mathrm{H}, m$, Ar-H), $10.37\left(1 \mathrm{H}\right.$, br.s, $\left.\mathrm{NH}^{+}\right)$; ${ }^{13} \mathrm{CNMR}: \delta 11.8,15.1,21.2,22.0,32.9,48.0,51.9,55.6,127.5$, 128,1, 129.2, 133.0, 141.4, 176.1, 199.1; HRMS $(m / z)$ : calculated value for $\left[\mathrm{M}+\mathrm{H}^{+}\right]$469.2486; found 469.2485 .

4.1.8. General Conditions of the Synthesis of New Alkanoloamine Derivatives of Dicarboximides (1b-1g, $\mathbf{2 b}-\mathbf{2 g}, \mathbf{3 b}-\mathbf{3 g}$ )

The new alkanolamine derivatives were obtained in two-step reactions according to the method described previously [10]. Step I: the mixture of an appropriate imide:

1: 1,7-dimethyl-8,9-diphenyl-4-azatricyclo[5.2.1.02,6]dec-8-ene-3,5,10-trione

2: 1,7-diethyl-8,9-diphenyl-4-azatricyclo[5.2.1.0 $0^{2,6}$ ]dec-8-ene-3,5,10-trione

3: 1,7,8,9-tetraphenyl-4-azatricyclo[5.2.1.0 $\left.0^{2,6}\right]$ dec-8-ene-3,5-dione

$(0.01 \mathrm{~mol})$ with 1-chloro-2,3-epoxypropane $(50-60 \mathrm{~mL})$, in the presence of an anhydrous $\mathrm{K}_{2} \mathrm{CO}_{3}(0.01 \mathrm{~mol})$ was stirred on a magnetic stirrer under reflux with a tube with $\mathrm{CaCl}_{2}$. The reaction was carried out. at room temperature for $15 \mathrm{~h}$. When the reaction was completed (TLC control), the inorganic precipitate was filtered off and the filtrate was concentrated. The obtained oily product was purified by column chromatography on silica gel (eluent: chloroform and chloroform/methanol 50:0.2). Step II: to the solution of an appropriate 4-(oxirane-2-ylmethyl)-4-imide (1a, 2a, 3a) $(0.001 \mathrm{~mol})$ in a mixture of methanol/water $(10: 1 v / v)$, the appropriate amine $(0.001 \mathrm{~mol})$ was added. Reactions were carried out at room temperature on a magnetic stirrer under reflux for $15-20 \mathrm{~h}$. When the reaction was completed (TLC control), the excess of the solvent was evaporated and the crude product was purified by column chromatography on silica gel (eluent: chloroform or chloroform/methanol (50:0.2, 50:0.5)).

4-[3-(ethylamino)-2-hydroxypropyl]-1,7-dimethyl-8,9-diphenyl-4-azatricyclo [5.2.1.0 $\left.{ }^{2,6}\right]$ dec-8-ene-3,5,10-trione (1b)

M.W. $=458.5488$ (free amine); $\mathrm{C}_{28} \mathrm{H}_{30} \mathrm{~N}_{2} \mathrm{O}_{4}{ }^{*} \mathrm{HCl}$; Yield: 55\%; white powder, m.p. 198$201{ }^{\circ} \mathrm{C}$ (from MeOH/(Et) $\left.)_{2} \mathrm{O}\right) ;{ }^{1} \mathrm{HNMR}\left(300 \mathrm{MHz}, \mathrm{DMSO}_{6}+\mathrm{TMS}, \delta / \mathrm{ppm}\right): 1.18(3 \mathrm{H}, t$, 
$\left.J=7.2 \mathrm{~Hz},-\mathrm{CH}_{3}\right), 1.42\left(6 \mathrm{H}, s,-\mathrm{CH}_{3}\right), 2.78(1 \mathrm{H}, m, \mathrm{C} 6-\mathrm{H}), 2.80\left(2 \mathrm{H}, m,-\mathrm{CH}_{2}-\right) 3.05(1 \mathrm{H}, m$, C2-H), 3.37(2H, $\left.m, \mathrm{C}^{\prime}-\mathrm{H}\right), 3.51\left(2 \mathrm{H}, m, \mathrm{C1}^{\prime}-\mathrm{H}\right), 4.10\left(1 \mathrm{H}, s, \mathrm{C}^{\prime}-\mathrm{H}\right), 5.88(1 \mathrm{H}, s,-\mathrm{OH}), 6.87$ $(4 \mathrm{H}, m, \mathrm{Ar}-\mathrm{H}), 7.18(6 \mathrm{H}, m, \mathrm{Ar}-\mathrm{H}), 8.65\left(1 \mathrm{H}, b r . s,-\mathrm{NH}_{2}{ }^{+}\right), 9.09\left(1 \mathrm{H}, b r . s,-\mathrm{NH}_{2}{ }^{+}\right) ;{ }^{13} \mathrm{CNMR}: \delta$ $10.7,11.8,42.3,42.7,47.4,47.6,49.3,55.7,63.4,127.5,128,1,129.3,133.2,141.3,175.8,176.2$, 199.4; HRMS $(m / z)$ : calculated value for $\left[\mathrm{M}+\mathrm{H}^{+}\right]$459.2284; found 459.2284.

4-[3-(tert-butylamino)-2-hydroxypropyl]-1,7-dimethyl-8,9-diphenyl-4-azatricyclo [5.2.1.0 ${ }^{2,6}$ ] dec-8-ene-3,5,10-trione (1c)

M.W. $=486.6019$ (free amine); $\mathrm{C}_{30} \mathrm{H}_{34} \mathrm{~N}_{2} \mathrm{O}_{4}{ }^{*} \mathrm{HCl}$; Yield: $57 \%$; white powder, m.p. 248$250{ }^{\circ} \mathrm{C}$ (from MeOH/(Et) $\left.)_{2} \mathrm{O}\right) ;{ }^{1} \mathrm{HNMR}\left(300 \mathrm{MHz}, \mathrm{DMSO}-\mathrm{d}_{6}+\mathrm{TMS}, \delta / \mathrm{ppm}\right): 1.26(9 \mathrm{H}, \mathrm{s}$, $\left.-\mathrm{C}\left(\mathrm{CH}_{3}\right)_{3}\right), 1.43\left(6 \mathrm{H}, d, J=5.1 \mathrm{~Hz},-\mathrm{CH}_{3}\right), 2.50(1 \mathrm{H}, m, \mathrm{C} 6-\mathrm{H}), 3.16(1 \mathrm{H}, m, \mathrm{C} 2-\mathrm{H}), 3.52(4 \mathrm{H}$, $\left.m, \mathrm{C}^{\prime}-\mathrm{H}, \mathrm{Cl}^{\prime}-\mathrm{H}\right), 4.14\left(1 \mathrm{H}, m, \mathrm{C}^{\prime}-\mathrm{H}\right), 5.83(1 \mathrm{H}, s,-\mathrm{OH}), 6.88(4 \mathrm{H}, m, \mathrm{Ar}-\mathrm{H}), 7.18(6 \mathrm{H}, m$, Ar-H), $8.39\left(1 \mathrm{H}\right.$, br.s, $\left.-\mathrm{NH}_{2}{ }^{+}\right), 9.04\left(1 \mathrm{H}\right.$, br.s, $\left.-\mathrm{NH}_{2}{ }^{+}\right) ;{ }^{13} \mathrm{CNMR}: \delta 11.8,24.9,42.8,44.5,47.3$, $47.6,48.5,55.6,56.2,63.7,127.4,128.0,129.3,133.2,141.3,175.7,176.3,199.4 ;$ HRMS $(m / z)$ : calculated value for $\left[\mathrm{M}+\mathrm{H}^{+}\right]$487.2598; found 487.2597.

4-[3-(diethylamino)-2-hydroxypropyl]-1,7-dimethyl-8,9-diphenyl-4-azatricyclo[5.2.1.0 $\left.{ }^{2,6}\right]$ dec-8-ene-3,5,10-trione (1d)

M.W. $=486.6019$ (free amine); $\mathrm{C}_{30} \mathrm{H}_{34} \mathrm{~N}_{2} \mathrm{O}_{4}{ }^{*} \mathrm{HCl}$; Yield: $72 \%$; white powder, m.p. 177$179{ }^{\circ} \mathrm{C}$ (from MeOH/ $\left.(\mathrm{Et}){ }_{2} \mathrm{O}\right) ;{ }^{1} \mathrm{HNMR}\left(300 \mathrm{MHz}, \mathrm{DMSO}-\mathrm{d}_{6}+\mathrm{TMS}, \delta / \mathrm{ppm}\right): 1.18(6 \mathrm{H}, t$, $\left.J=7.2 \mathrm{~Hz},-\mathrm{CH}_{3}\right), 1.42\left(6 \mathrm{H}, d, J=4.2 \mathrm{~Hz},-\mathrm{CH}_{3}\right), 3.16\left(6 \mathrm{H}, m, \mathrm{C} 6-\mathrm{H}, \mathrm{C} 2-\mathrm{H}, \mathrm{C}^{\prime}-\mathrm{H}, \mathrm{C} 1^{\prime}-\mathrm{H}\right)$, $3.52\left(2 \mathrm{H}, m,-\mathrm{CH}_{2}-\right), 3.73(2 \mathrm{H}, \mathrm{m},-\mathrm{CH} 2-), 4.19(1 \mathrm{H}, \mathrm{s},-\mathrm{OH}), 6.87(4 \mathrm{H}, m, \mathrm{Ar}-\mathrm{H}), 7.17(6 \mathrm{H}, m$, Ar-H), $9.87\left(1 \mathrm{H}\right.$, br.s, $\left.-\mathrm{NH}^{+}\right) ;{ }^{13} \mathrm{CNMR}: \delta 8.3,11.8,42.8,46.7,47.4,47.6,54.0,55.7,62.5,127.5$, 128.0, 129.3, 133.1, 141.3, 175.8, 176.2, 199.3; $\operatorname{HRMS}(m / z)$ : calculated value for $\left[\mathrm{M}+\mathrm{H}^{+}\right]$ 487.2598; found 487.2597.

4-[3-(dibutylamino)-2-hydroxypropyl]-1,7-dimethyl-8,9-diphenyl-4-azatricyclo [5.2.1.0 $\left.{ }^{2,6}\right]$ dec-8-ene-3,5,10-trione (1e)

M.W. $=542.7082$ (free amine); $\mathrm{C}_{34} \mathrm{H}_{42} \mathrm{~N}_{2} \mathrm{O}_{4}{ }^{*} \mathrm{HCl}$; Yield: $74 \%$; white powder, m.p. 192 $196{ }^{\circ} \mathrm{C}$ (from $\left.\mathrm{MeOH} /(\mathrm{Et})_{2} \mathrm{O}\right) ;{ }^{1} \mathrm{HNMR}\left(300 \mathrm{MHz}, \mathrm{DMSO}-\mathrm{d}_{6}+\mathrm{TMS}, \delta / \mathrm{ppm}\right): 0.89(6 \mathrm{H}, t$, $\left.J=7.35 \mathrm{~Hz},-\mathrm{CH}_{3}\right), 1.27\left(4 \mathrm{H}, m,-\mathrm{CH}_{2}-\right), 1.42\left(6 \mathrm{H}, d, J=4.2 \mathrm{~Hz},-\mathrm{CH}_{3}\right), 1.60\left(4 \mathrm{H}, m,-\mathrm{CH}_{2}-\right)$, $3.05\left(4 \mathrm{H}, m,-\mathrm{CH}_{2}-\right), 3.20(1 \mathrm{H}, m, \mathrm{C} 6-\mathrm{H}), 3.31\left(2 \mathrm{H}, m, \mathrm{C}^{\prime}-\mathrm{H}\right), 3.51\left(3 \mathrm{H}, m, \mathrm{C1}^{\prime}-\mathrm{H}, \mathrm{C} 2^{\prime}-\mathrm{H}\right)$, $4.19\left(1 \mathrm{H}, m, \mathrm{C} 2^{\prime}-\mathrm{H}\right) 5.94(1 \mathrm{H}, s,-\mathrm{OH}), 6.88(4 \mathrm{H}, m, \mathrm{Ar}-\mathrm{H}), 7.17(6 \mathrm{H}, m, \mathrm{Ar}-\mathrm{H}), 9.81(1 \mathrm{H}$, br.s, -NH $\left.{ }^{+}\right) ;{ }^{13} \mathrm{CNMR}: \delta 11.8,13.4,19.3,24.5,47.4,47.6,52.2,52.8,55.1,55.7,62.6,127.5,128.0$, $129.3,133.1,141.3,175.8,176.2,199.2$; HRMS $(m / z)$ : calculated value for $\left[\mathrm{M}+\mathrm{H}^{+}\right] 543.3224$; found 543.3223 .

4-[2-hydroxy-3-(piperidin-1-yl)propyl]-1,7-dimethyl-8,9-diphenyl-4-azatricyclo[5.2.1.0 $\left.{ }^{2,6}\right]$ dec-8-ene-3,5,10-trione (1f)

M.W. $=498.6126$ (free amine); $\mathrm{C}_{31} \mathrm{H}_{34} \mathrm{~N}_{2} \mathrm{O}_{4}{ }^{*} \mathrm{HCl}$; Yield: $45 \%$; white powder, m.p. 170 $171{ }^{\circ} \mathrm{C}$ (from MeOH/(Et) $\left.{ }_{2} \mathrm{O}\right) ;{ }^{1} \mathrm{HNMR}\left(300 \mathrm{MHz}, \mathrm{DMSO}-\mathrm{d}_{6}+\mathrm{TMS}, \delta / \mathrm{ppm}\right): 1.42(6 \mathrm{H}, \mathrm{m}$, $\left.-\mathrm{CH}_{3}\right), 1.74\left(4 \mathrm{H}, m,-\mathrm{CH}_{2}\right.$-pip), $2.50\left(3 \mathrm{H}, \mathrm{m}, \mathrm{C} 6-\mathrm{H}, \mathrm{C}^{\prime}-\mathrm{H}\right), 2.88\left(2 \mathrm{H}, m,-\mathrm{Cl}^{\prime}-\mathrm{H}\right), 3.32(7 \mathrm{H}$, $m, \mathrm{C} 2-\mathrm{H},-\mathrm{CH}_{2}$-pip), $4.42\left(1 \mathrm{H}, \mathrm{m}, \mathrm{C} 2^{\prime}-\mathrm{H}\right) 5.97(1 \mathrm{H}, \mathrm{s},-\mathrm{OH}), 6.88(4 \mathrm{H}, m, \mathrm{Ar}-\mathrm{H}), 7.18(6 \mathrm{H}, m$, Ar-H), $9.97\left(1 \mathrm{H}\right.$, br.s, $\left.-\mathrm{NH}^{+}\right) ;{ }^{13} \mathrm{CNMR}: \delta 11.8,21.2,22.1,42.7,47.6,52.1,53.4,55.6,58.7,62.3$, $127.5,128.0,129.3,133.1,141.4,175.8,176.1,199.3$; HRMS $(\mathrm{m} / \mathrm{z})$ : calculated value for $[\mathrm{M}+$ $\left.\mathrm{H}^{+}\right]$499.2598; found 499.2597 .

4-[-2-hydroxy-3-(morpholin-4-yl)propyl]-1,7-dimethyl-8,9-diphenyl-4-azatricyclo [5.2.1.0 $\left.{ }^{2,6}\right]$ dec-8-ene-3,5,10-trione (1g)

M.W. $=500.5854$ (free amine); $\mathrm{C}_{30} \mathrm{H}_{32} \mathrm{~N}_{2} \mathrm{O}_{5}{ }^{*} \mathrm{HCl}$; Yield: $54 \%$; white powder, m.p. 210 $212{ }^{\circ} \mathrm{C}$ (from $\left.\mathrm{MeOH} /(\mathrm{Et})_{2} \mathrm{O}\right) ;{ }^{1} \mathrm{HNMR}\left(300 \mathrm{MHz}, \mathrm{DMSO}-\mathrm{d}_{6}+\mathrm{TMS}, \delta / \mathrm{ppm}\right): 1.42(6 \mathrm{H}$, $\left.m,-\mathrm{CH}_{3}\right), 3.07(2 \mathrm{H}, m, \mathrm{C} 2-\mathrm{H}, \mathrm{C} 6-\mathrm{H}), 3.38\left(6 \mathrm{H}, m,-\mathrm{CH}_{2}\right.$-morpholin), $3.52\left(2 \mathrm{H}, m,-\mathrm{CH}_{2}-\right.$ morpholin), $3.88\left(4 \mathrm{H}, m, \mathrm{C}^{\prime}-\mathrm{H}, \mathrm{C1}^{\prime}-\mathrm{H}\right), 4.30\left(1 \mathrm{H}, m, \mathrm{C} 2^{\prime}-\mathrm{H}\right), 6.01(1 \mathrm{H}, s,-\mathrm{OH}), 6.87(4 \mathrm{H}, m$, Ar-H), $7.18(6 \mathrm{H}, m, \mathrm{Ar}-\mathrm{H}), 10.07\left(1 \mathrm{H}\right.$, br.s, $\left.-\mathrm{NH}^{+}\right) ;{ }^{13} \mathrm{CNMR}: \delta 11.8,42.6,47.5,51.0,52.5,55.6$, 
$58.7,62.2,62.9,127.5,128.1,129.3,133.1,141.4,175.8,176.1,199.3 ; \operatorname{HRMS}(\mathrm{m} / \mathrm{z})$ : calculated value for $\left[\mathrm{M}+\mathrm{H}^{+}\right]$501.2384; found 501.2379.

4-[3-(ethylamino)-2-hydroxypropyl]-1,7-diethyl-8,9-diphenyl-4-azatricyclo [5.2.1.0 2,6]dec8-ene-3,5,10-trione (2b)

M.W. = 486.6019 (free amine); $\mathrm{C}_{30} \mathrm{H}_{34} \mathrm{~N}_{2} \mathrm{O}_{4}{ }^{*} \mathrm{HCl}$; Yield: 55\%; white powder, m.p. 197$200{ }^{\circ} \mathrm{C}$ (from MeOH/(Et) $\left.{ }_{2} \mathrm{O}\right) ;{ }^{1} \mathrm{HNMR}\left(300 \mathrm{MHz}, \mathrm{DMSO}-\mathrm{d}_{6}+\mathrm{TMS}, \delta / \mathrm{ppm}\right): 0.89(6 \mathrm{H}, m$, $\left.-\mathrm{CH}_{3}\right), 1.18\left(3 \mathrm{H}, t, J=7.2 \mathrm{~Hz},-\mathrm{CH}_{3}\right), 1.87\left(2 \mathrm{H}, m,-\mathrm{CH}_{2}-\right), 2.11\left(2 \mathrm{H}, m,-\mathrm{CH}_{2}-\right), 2.80(1 \mathrm{H}, m$, C6-H), $2.88\left(2 \mathrm{H}, m,-\mathrm{CH}_{2}-\right) 3.06(1 \mathrm{H}, m, \mathrm{C} 2-\mathrm{H}), 3.41\left(2 \mathrm{H}, m, \mathrm{C}^{\prime}-\mathrm{H}\right), 3.54\left(2 \mathrm{H}, m, \mathrm{C}^{\prime}-\mathrm{H}\right), 4.13$ $(1 \mathrm{H}, s, \mathrm{C} 2$ '-H), 5.89 (1H, br.s, $-\mathrm{OH}), 6.87(4 \mathrm{H}, m, \mathrm{Ar}-\mathrm{H}), 7.16(6 \mathrm{H}, m, \mathrm{Ar}-\mathrm{H}), 8.67$ (1H, br.s, $\left.-\mathrm{NH}_{2}{ }^{+}\right), 9.10\left(1 \mathrm{H}\right.$, br.s, $\left.-\mathrm{NH}_{2}{ }^{+}\right)$; ${ }^{13} \mathrm{CNMR}: \delta$ 9.0, 10.7, 18.9, 39.5, 42.2, 42.7, 43.6, 43.7, 49.2, 59.2, 63.3, 127.4, 128.0, 129.2, 133.5, 141.7, 141.8, 176.0, 176.4, 199.0; HRMS ( $\mathrm{m} / \mathrm{z})$ : calculated value for $\left[\mathrm{M}+\mathrm{H}^{+}\right]$487.6093; found 487.2591 .

4-[3-(tert-butylamino)-2-hydroxypropyl]-1,7-diethyl-8,9-diphenyl-4-azatricyclo [5.2.1.0 $\left.{ }^{2,6}\right]$ dec-8-ene-3,5,10-trione (2c)

M.W. = 514.6551 (free amine); $\mathrm{C}_{32} \mathrm{H}_{38} \mathrm{~N}_{2} \mathrm{O}_{4}{ }^{*} \mathrm{HCl}$; Yield: 67\%; white powder, m.p. 231$235{ }^{\circ} \mathrm{C}$ (from MeOH/(Et) $\left.2 \mathrm{O}\right) ;{ }^{1} \mathrm{HNMR}\left(300 \mathrm{MHz}, \mathrm{DMSO}-\mathrm{d}_{6}+\mathrm{TMS}, \delta / \mathrm{ppm}\right): 0.88(6 \mathrm{H}, d, J$ $\left.=5.1 \mathrm{~Hz},-\mathrm{CH}_{3}\right), 1.26\left(9 \mathrm{H}, m,-\mathrm{C}\left(\mathrm{CH}_{3}\right)_{3}\right), 1.87\left(2 \mathrm{H}, m,-\mathrm{CH}_{2}-\right), 2.09\left(2 \mathrm{H}, \mathrm{m},-\mathrm{CH}_{2}-\right), 2.78(1 \mathrm{H}$, $m, \mathrm{C} 6-\mathrm{H}), 3.08(1 \mathrm{H}, m, \mathrm{C} 2-\mathrm{H}), 3.40\left(2 \mathrm{H}, m, \mathrm{C}^{\prime}-\mathrm{H} 0,3.69\left(2 \mathrm{H}, m, \mathrm{C}^{\prime}-\mathrm{H}\right), 4.14\left(1 \mathrm{H}, m, \mathrm{C} 2^{\prime}-\mathrm{H}\right)\right.$, $5.80(1 \mathrm{H}, s,-\mathrm{OH}), 6.88(4 \mathrm{H}, m, \mathrm{Ar}-\mathrm{H}), 7.16(6 \mathrm{H}, m, \mathrm{Ar}-\mathrm{H}), 8.36\left(1 \mathrm{H}\right.$, br.s, $\left.-\mathrm{NH}_{2}{ }^{+}\right), 8.86(1 \mathrm{H}$, br.s, $\left.-\mathrm{NH}_{2}{ }^{+}\right) ;{ }^{13} \mathrm{CNMR}: \delta$ 9.0, 18.8, 24.9, 42.9, 43.6, 44.3, 56.2, 59.2, 59.3, 63.6, 127.4, 128.0, $129.1,133.5,133.5,141.7,141.8,175.9,176.5,198.9$; HRMS $(m / z)$ : calculated value for $[\mathrm{M}+$ $\mathrm{H}^{+}$] 515.6625; found 515.2904.

4-[3-(diethylamino)-2-hydroxypropyl]-1,7-diethyl-8,9-diphenyl-4-azatricyclo [5.2.1.0 $\left.{ }^{2,6}\right]$ dec-8-ene-3,5,10-trione (2d)

M.W. = 514.6551 (free amine); $\mathrm{C}_{30} \mathrm{H}_{34} \mathrm{~N}_{2} \mathrm{O}_{4}{ }^{*} \mathrm{HCl}$; Yield: 62\%; white powder, m.p. 177$180{ }^{\circ} \mathrm{C}$ (from MeOH/(Et) $\left.2 \mathrm{O}\right) ;{ }^{1} \mathrm{HNMR}\left(300 \mathrm{MHz}, \mathrm{DMSO}-\mathrm{d}_{6}+\mathrm{TMS}, \delta / \mathrm{ppm}\right): 0.88(6 \mathrm{H}, m$, $\left.-\mathrm{CH}_{3}\right), 1.19\left(6 \mathrm{H}, t, J=\cdot 7.1 \mathrm{~Hz},-\mathrm{CH}_{3}\right), 2.06\left(2 \mathrm{H}, m,-\mathrm{CH}_{2}-\right), 2.08\left(2 \mathrm{H}, m,-\mathrm{CH}_{2}-\right), 3.16(6 \mathrm{H}, m$, C6-H, C2-H, C3'-H, C1'-H), 3.51 (4H, m, - $\left.\mathrm{CH}_{2}-\right), 4.20\left(1 \mathrm{H}, \mathrm{m}, \mathrm{C} 2^{\prime}-\mathrm{H}\right), 5.98(1 \mathrm{H}$, br. s, $-\mathrm{OH})$, $6.88(4 \mathrm{H}, m, \mathrm{Ar}-\mathrm{H}), 7.16(6 \mathrm{H}, m, \mathrm{Ar}-\mathrm{H}), 9.87\left(1 \mathrm{H}\right.$, br.s,$\left.-\mathrm{NH}^{+}\right) ;{ }^{13} \mathrm{CNMR}: \delta 9.3,9.0,18.8,42.8$, 43.7, 46.7, 47.4, 48.5, 54.0, 59.2, 62.5, 127.4, 128.0, 129.1, 133.5, 141.7, 176.0, 176.4, 199.0; $\operatorname{HRMS}(m / z)$ : calculated value for $\left[\mathrm{M}+\mathrm{H}^{+}\right]$515.6625; found 515.2904.

4-[3-(dibutylamino)-2-hydroxypropyl]-1,7-diethyl-8,9-diphenyl-4-azatricyclo[5.2.1.0 $\left.{ }^{2,6}\right]$ dec-8-ene-3,5,10-trione (2e)

M.W. = 570.7614 (free amine); $\mathrm{C}_{36} \mathrm{H}_{46} \mathrm{~N}_{2} \mathrm{O}_{4}{ }^{*} \mathrm{HCl}$; Yield: $64 \%$; white powder, m.p. $92-110{ }^{\circ} \mathrm{C}$

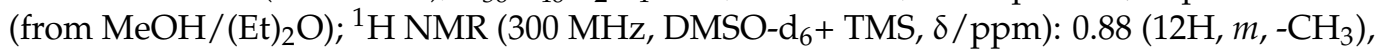
$1.29\left(4 \mathrm{H}, m,-\mathrm{CH}_{2}-\right), 1.62\left(4 \mathrm{H}, m,-\mathrm{CH}_{2}-\right), 1.87\left(2 \mathrm{H}, m,-\mathrm{CH}_{2}-\right), 2.07\left(2 \mathrm{H}, m,-\mathrm{CH}_{2}-\right), 3.06(4 \mathrm{H}$, $\left.m,-\mathrm{CH}_{2}-\right), 3.19(2 \mathrm{H}, m, \mathrm{C} 3-\mathrm{H}), 3.52\left(2 \mathrm{H}, m, \mathrm{C}^{\prime}-\mathrm{H}\right), 3.70(2 \mathrm{H}, m, \mathrm{C} 2-\mathrm{H}, \mathrm{C} 6-\mathrm{H}), 4.23(1 \mathrm{H}, m$, $\left.\mathrm{C} 2^{\prime}-\mathrm{H}\right), 6.88(4 \mathrm{H}, m, \mathrm{Ar}-\mathrm{H}), 7.16(6 \mathrm{H}, m, \mathrm{Ar}-\mathrm{H}), 9.99\left(1 \mathrm{H}\right.$, br.s, $\left.-\mathrm{NH}^{+}\right) ;{ }^{13} \mathrm{CNMR}: \delta 9.0,13.5$, $18.9,19.4,24.5,42.8,43.6,52.3,52.7,55.2,59.2,62.6,127.4,127.9,129.1,133.5,141.7,176.0$, 176.4, 198.9; HRMS $(m / z)$ : calculated value for $\left[\mathrm{M}+\mathrm{H}^{+}\right] 571.7688$; found 571.3530 .

4-[2-hydroxy-3-(piperidin-1-yl)propyl]-1,7-diethyl-8,9-diphenyl-4-azatricyclo[5.2.1.0 $\left.{ }^{2,6}\right]$ dec-8-ene-3,5,10-trione (2f)

M.W. $=526.6658$ (free amine); $\mathrm{C}_{33} \mathrm{H}_{38} \mathrm{~N}_{2} \mathrm{O}_{4}{ }^{*} \mathrm{HCl}$; Yield: 55\%; white powder, m.p. 190$195{ }^{\circ} \mathrm{C}$ (from MeOH/(Et) $\left.2 \mathrm{O}\right) ;{ }^{1} \mathrm{HNMR}\left(300 \mathrm{MHz}, \mathrm{DMSO}-\mathrm{d}_{6}+\mathrm{TMS}, \delta / \mathrm{ppm}\right): 0.89$ (6H, $m$, $\left.-\mathrm{CH}_{3}\right), 1.36\left(2 \mathrm{H}, m,-\mathrm{CH}_{2}-\right), 1.74\left(4 \mathrm{H}, m,-\mathrm{CH}_{2-},-\mathrm{CH}_{2}-\mathrm{pip}\right), 1.87$ (2H, m, - $\mathrm{CH}_{2}$-pip), 2.07 (2H, m, - $\mathrm{CH}_{2}$-pip), 2.90 (4H, m, C3'-H, - $\mathrm{CH}_{2}$-pip), 3.16 (2H, m, - $\mathrm{CH}_{2}$-pip), 3.46 (1H, m, C6-H), 3.49 (2H, C1'-H, C2-H), 4.26 (1H, m, C2' $-\mathrm{H}), 6.87$ (4H, m, Ar-H), 7.16 (6H, m, Ar-H), 10.08 $\left(1 \mathrm{H}\right.$, br.s, $\left.-\mathrm{NH}^{+}\right) ;{ }^{13} \mathrm{CNMR}: \delta 9.0,18.8,21.2,22.1,42.7,43.7,52.1,53.3,58.8,59.2,62.3,127.4$, 128.0, 129.1, 133.5, 141.7, 176.0, 176.3, 199.01; HRMS $(m / z)$ : calculated value for $\left[\mathrm{M}+\mathrm{H}^{+}\right]$ 527.6732; found 527.2904. 
4-[-2-hydroxy-3-(morpholin-4-yl)propyl]-1,7-diethyl-8,9-diphenyl-4-azatricyclo[5.2.1.0 $\left.{ }^{2,6}\right]$ dec-8-ene-3,5,10-trione (2g)

M.W. $=528.6386$ (free amine); $\mathrm{C}_{32} \mathrm{H}_{36} \mathrm{~N}_{2} \mathrm{O}_{5}{ }^{*} \mathrm{HCl}$; Yield: $54 \%$; white powder, m.p. 226$228{ }^{\circ} \mathrm{C}$ (from $\left.\mathrm{MeOH} /(\mathrm{Et})_{2} \mathrm{O}\right) ;{ }^{1} \mathrm{HNMR}\left(300 \mathrm{MHz}, \mathrm{DMSO}-\mathrm{d}_{6}+\mathrm{TMS}, \delta / \mathrm{ppm}\right): 0.89(6 \mathrm{H}$, $\left.m,-\mathrm{CH}_{3}\right), 1.87\left(2 \mathrm{H}, m,-\mathrm{CH}_{2}-\right), 2.06\left(2 \mathrm{H}, m,-\mathrm{CH}_{2}-\right), 3.1(3 \mathrm{H}, m, \mathrm{C} 3-\mathrm{H}, \mathrm{C} 6-\mathrm{H}), 3.36(3 \mathrm{H}$, $m$, - $\mathrm{CH}_{2}$-morpholin, $\left.\mathrm{C} 2-\mathrm{H}\right), 3.47\left(4 \mathrm{H}, m,-\mathrm{CH}_{2}\right.$-morpholin), $3.89\left(4 \mathrm{H}, m,-\mathrm{CH}_{2}\right.$-morpholin, $\left.\mathrm{C}^{\prime}-\mathrm{H}\right), 4.30\left(1 \mathrm{H}, m, \mathrm{C}^{\prime}-\mathrm{H}\right), 6.01(1 \mathrm{H}$, br.s, $-\mathrm{OH}), 6.87(4 \mathrm{H}, m, \mathrm{Ar}-\mathrm{H}), 7.68(6 \mathrm{H}, m, \mathrm{Ar}-\mathrm{H})$, $10.57\left(1 \mathrm{H}\right.$, br.s, $\left.-\mathrm{NH}^{+}\right) ;{ }^{13} \mathrm{CNMR}: \delta 9.0,18.8,39.5,43.7,51.0,52.5,58.8,59.2,62.1,62.9,127.4$, 128.0, 129.1, 133.5, 141.7, 176.0, 176.3, 199.0; $\operatorname{HRMS}(m / z)$ : calculated value for $\left[\mathrm{M}+\mathrm{H}^{+}\right]$ 529.6460; found 529.2697.

4-[3-(ethylamino)-2-hydroxypropyl]-1,7,8,9-tetraphenyl-4-azatricyclo[5.2.1.0 $\left.{ }^{2,6}\right]$ dec-8-ene3,5-dione (3b)

M.W. $=568.7040$ (free amine); $\mathrm{C}_{38} \mathrm{H}_{36} \mathrm{~N}_{2} \mathrm{O}_{3}{ }^{*} \mathrm{HCl}$; Yield: $45 \%$; white powder, m.p. 254 $255^{\circ} \mathrm{C}$ (from $\left.\mathrm{MeOH} /(\mathrm{Et})_{2} \mathrm{O}\right) ;{ }^{1} \mathrm{HNMR}\left(300 \mathrm{MHz}, \mathrm{DMSO}-\mathrm{d}_{6}+\mathrm{TMS}, \delta / \mathrm{ppm}\right): 1.19(3 \mathrm{H}, t$, $\left.J=7.2 \mathrm{~Hz},-\mathrm{CH}_{3}\right), 2.34(1 \mathrm{H}, m, \mathrm{C} 10-\mathrm{H}), 2.78(1 \mathrm{H}, m, \mathrm{C} 10-\mathrm{H}), 2.91\left(2 \mathrm{H}, m,-\mathrm{CH}_{2}-\right) 3.05(1 \mathrm{H}, m$, $\mathrm{C} 2-\mathrm{H}), 3.16(1 \mathrm{H}, \mathrm{m}, \mathrm{C} 6-\mathrm{H}), 3.30\left(2 \mathrm{H}, m, \mathrm{C}^{\prime}-\mathrm{H}\right), 3.46\left(1 \mathrm{H}, s, \mathrm{C}^{\prime}-\mathrm{H}\right), 4.29\left(2 \mathrm{H}, m, \mathrm{C1}^{\prime}-\mathrm{H}\right), 5.85$ $(1 \mathrm{H}, s,-\mathrm{OH}), 6.51(4 \mathrm{H}, m, \mathrm{Ar}-\mathrm{H}), 6.88(6 \mathrm{H}, m, \mathrm{Ar}-\mathrm{H}), 7.32(6 \mathrm{H}, m, \mathrm{Ar}-\mathrm{H}), 7.76(4 \mathrm{H}, m, \mathrm{Ar}-\mathrm{H})$, $8.60\left(1 \mathrm{H}\right.$, br.s, $\left.-\mathrm{NH}_{2}{ }^{+}\right), 8.94\left(1 \mathrm{H}\right.$, br.s, $\left.-\mathrm{NH}_{2}{ }^{+}\right) ;{ }^{13} \mathrm{CNMR}: \delta 10.7,42.2,49.4,51.9,63.0,63.4$, $65.1,126.5,126.8,127.2,127.8,129.2,129.5,134.4,139.7,145.1,176.6,176.9$; HRMS $(m / z)$ : calculated value for $\left[\mathrm{M}+\mathrm{H}^{+}\right]$569.7119; found 569.2798.

4-[3-(tert-butylamino)-2-hydroxypropyl]-1,7,8,9-tetraphenyl-4-azatricyclo[5.2.1.0 $\left.{ }^{2,6}\right]$ dec8-ene-3,5-dione (3c)

M.W. $=596.7575$ (free amine); $\mathrm{C}_{40} \mathrm{H}_{40} \mathrm{~N}_{2} \mathrm{O}_{3}{ }^{*} \mathrm{HCl}$; Yield: $60 \%$; white powder, m.p. 177$179{ }^{\circ} \mathrm{C}$ (from MeOH/ $\left.(\mathrm{Et})_{2} \mathrm{O}\right) ;{ }^{1} \mathrm{HNMR}\left(300 \mathrm{MHz}, \mathrm{DMSO}-\mathrm{d}_{6}+\mathrm{TMS}, \delta / \mathrm{ppm}\right): 1.28(9 \mathrm{H}, \mathrm{s}$, $\left.-\mathrm{C}\left(\mathrm{CH}_{3}\right)_{3}\right), 2.36(1 \mathrm{H}, d, J=8.7 \mathrm{~Hz} \mathrm{C} 6-\mathrm{H}), 2.76(1 \mathrm{H}, m, \mathrm{C} 10-\mathrm{H}), 3.06(1 \mathrm{H}, m, \mathrm{C} 10-\mathrm{H}), 3.27(1 \mathrm{H}$, $m, \mathrm{C} 2-\mathrm{H}), 3.35\left(4 \mathrm{H}, m, \mathrm{C}^{\prime}-\mathrm{H}, \mathrm{C}^{\prime}-\mathrm{H}\right), 3.52\left(1 \mathrm{H}, m, \mathrm{C}^{\prime}-\mathrm{H}\right), 4.21(1 \mathrm{H}, s,-\mathrm{OH}), 6.51(4 \mathrm{H}, m$, Ar-H), $6.88(6 \mathrm{H}, m, \mathrm{Ar}-\mathrm{H}), 7.31(6 \mathrm{H}, m, \mathrm{Ar}-\mathrm{H}), 7.76(4 \mathrm{H}, m, \mathrm{Ar}-\mathrm{H}), 8.41\left(1 \mathrm{H}\right.$, br.s, $\left.-\mathrm{NH}_{2}{ }^{+}\right), 9.06$ $\left(1 \mathrm{H}\right.$, br.s, $\left.-\mathrm{NH}_{2}{ }^{+}\right) ;{ }^{13} \mathrm{CNMR}: \delta 24.9,42.7,44.6,51.7,52.0,56.2,63.0,63.7,65.1,126.4,126.5$, 127.2, 127.8, 129.1, 129.5, 134.4, 139.7, 145.0, 145.1, 176.5, 177.0; HRMS $(m / z)$ : calculated value for $\left[\mathrm{M}+\mathrm{H}^{+}\right]$597.7651; found 597.3117.

4-[3-(diethylamino)-2-hydroxypropyl]-1,7,8,9-tetraphenyl-4-azatricyclo[5.2.1.0 $\left.{ }^{2,6}\right]$ dec-8ene-3,5-dione (3d)

M.W. $=596.7575$ (free amine); $\mathrm{C}_{40} \mathrm{H}_{40} \mathrm{~N}_{2} \mathrm{O}_{3}{ }^{*} \mathrm{HCl}$; Yield: $62 \%$; white powder, m.p. 240 $247^{\circ} \mathrm{C}$ (from $\left.\mathrm{MeOH} /(\mathrm{Et})_{2} \mathrm{O}\right) ;{ }^{1} \mathrm{HNMR}\left(300 \mathrm{MHz}, \mathrm{DMSO}-\mathrm{d}_{6}+\mathrm{TMS}, \delta / \mathrm{ppm}\right): 1.20(6 \mathrm{H}, t$, $\left.J=7.2 \mathrm{~Hz},-\mathrm{CH}_{3}\right), 2.33(1 \mathrm{H}, d, J=8.4 \mathrm{~Hz}, \mathrm{C} 6-\mathrm{H}), 3.16\left(6 \mathrm{H}, m,-\mathrm{CH}_{2}^{-},-\mathrm{CH}_{2}-\mathrm{C}^{\prime}-\mathrm{H}, \mathrm{C1}{ }^{\prime}-\mathrm{H}\right)$, $3.38(1 \mathrm{H}, m, \mathrm{C} 2-\mathrm{H}), 3.50\left(1 \mathrm{H}, m, \mathrm{C} 2{ }^{\prime}-\mathrm{H}\right), 4.26(2 \mathrm{H}, m, \mathrm{C} 10-\mathrm{H}), 5.98(1 \mathrm{H}, s,-\mathrm{OH}), 6.52(4 \mathrm{H}$, $m, \mathrm{Ar}-\mathrm{H}), 6.88(6 \mathrm{H}, m, \mathrm{Ar}-\mathrm{H}), 7.31(6 \mathrm{H}, m, \mathrm{Ar}-\mathrm{H}), 7.77(4 \mathrm{H}, m, \mathrm{Ar}-\mathrm{H}), 9.93\left(1 \mathrm{H}\right.$, br.s, $\left.-\mathrm{NH}^{+}\right)$; ${ }^{13}$ CNMR: $\delta 8.4,42.7,46.7,47.4,51.9,52.0,54.2,62.5,63.0,65.1,126.5,126.8,127.2,127.8$, $129.2,129.5,134.4,139.7,145.0,145.1,176.6,177.0$; HRMS $(m / z)$ : calculated value for $[\mathrm{M}+$ $\mathrm{H}^{+}$] 597.7651; found 597.3117.

4-[3-(dibutylamino)-2-hydroxypropyl]-1,7,8,9-tetraphenyl-4-azatricyclo[5.2.1.0 $\left.{ }^{2,6}\right]$ dec-8ene-3,5-dione (3e)

M.W. $=652.8635$ (free amine); $\mathrm{C}_{44} \mathrm{H}_{48} \mathrm{~N}_{2} \mathrm{O}_{3}{ }^{*} \mathrm{HCl}$; Yield: 64\%; white powder, m.p. 237$238^{\circ} \mathrm{C}$ (from MeOH/(Et) $\left.)_{2} \mathrm{O}\right) ;{ }^{1} \mathrm{HNMR}\left(300 \mathrm{MHz}, \mathrm{DMSO}_{6}+\mathrm{TMS}, \delta / \mathrm{ppm}\right): 0.90(6 \mathrm{H}, t$, $\left.J=7.2 \mathrm{~Hz},-\mathrm{CH}_{3}\right), 1.29\left(4 \mathrm{H}, m,-\mathrm{CH}_{2}-\right), 1.62\left(4 \mathrm{H}, m,-\mathrm{CH}_{2}-\right), 2.37(1 \mathrm{H}, m, \mathrm{C} 6-\mathrm{H}), 3.16(4, m$, $\left.-\mathrm{CH}_{2}-\right), 3.34\left(8 \mathrm{H}, m, \mathrm{C} 2-\mathrm{H}, \mathrm{C}^{\prime}-\mathrm{H}, \mathrm{C}^{\prime}-\mathrm{H}, \mathrm{C}^{\prime}-\mathrm{H}, \mathrm{C} 10-\mathrm{H}\right), 5.94(1 \mathrm{H}, s,-\mathrm{OH}), 6.51(4 \mathrm{H}, m$, Ar-H), 6.88 (6H, m, Ar-H), $7.31(6 \mathrm{H}, m, \mathrm{Ar}-\mathrm{H}), 7.74(4 \mathrm{H}, m, \mathrm{Ar}-\mathrm{H}), 9.71\left(1 \mathrm{H}\right.$, br.s, $\left.-\mathrm{NH}^{+}\right)$; ${ }^{13}$ CNMR: $\delta$ 13.5, 19.4, 24.6, 48.5, 51.8, 52.0, 52.3, 52.7, 55.4, 62.6, 63.0, 65.1, 126.5, 126.8, 127.3, $127.8,129.2,129.5,134.4,139.7,145.0,145.1,176.6,177.0$; HRMS $(\mathrm{m} / \mathrm{z})$ : calculated value for $\left[\mathrm{M}+\mathrm{H}^{+}\right]$653.8714; found 653.3743. 
4-[2-hydroxy-3-(piperidin-1-yl)propyl]-1,7,8,9-tetraphenyl-4-azatricyclo[5.2.1.0 $\left.{ }^{2,6}\right]$ dec-8ene-3,5-dione (3f)

M.W. $=608.7679$ (free amine); $\mathrm{C}_{41} \mathrm{H}_{40} \mathrm{~N}_{2} \mathrm{O}_{3}{ }^{*} \mathrm{HCl}$; Yield: $54 \%$; white powder, m.p. 268$270{ }^{\circ} \mathrm{C}$ (from MeOH/ $\left.(\mathrm{Et}){ }_{2} \mathrm{O}\right) ;{ }^{1} \mathrm{HNMR}\left(300 \mathrm{MHz}, \mathrm{DMSO}_{\mathrm{d}}+\mathrm{TMS}, \delta / \mathrm{ppm}\right): 1.35(1 \mathrm{H}, \mathrm{m}$, C2-H), 1.75 (5H, m, -CH $\mathrm{CH}_{2}$-pip., C6-H), $2.36(1 \mathrm{H}, m, \mathrm{C} 10-\mathrm{H}), 2.88\left(2 \mathrm{H}, \mathrm{m}, \mathrm{C1}^{\prime}-\mathrm{H}\right), 2.99(1 \mathrm{H}$, $\left.m, \mathrm{C}^{\prime}-\mathrm{H}\right), 3.40\left(9 \mathrm{H}, m,-\mathrm{CH}_{2}-\mathrm{pip}, \mathrm{C}^{\prime}-\mathrm{H}, \mathrm{C} 10-\mathrm{H}\right), 5.98(1 \mathrm{H}, s,-\mathrm{OH}), 6.51(6 \mathrm{H}, m, \mathrm{Ar}-\mathrm{H})$, $6.88(4 \mathrm{H}, m, \mathrm{Ar}-\mathrm{H}), 7.31(6 \mathrm{H}, m, \mathrm{Ar}-\mathrm{H}), 7.74(4 \mathrm{H}, m, \mathrm{Ar}-\mathrm{H}), 9.93\left(1 \mathrm{H}\right.$, br.s, $\left.-\mathrm{NH}^{+}\right) ;{ }^{13} \mathrm{CNMR}$ : $\delta$ 21.22, 22.1, 42.6, 51.9, 53.4, 59.0, 62.28, 63.0, 65.1, 126.5, 126.7, 127.2, 127.8, 129.1, 129.5, 134.3, 139.7, 144.9, 145.1, 176.6, 176.9; HRMS $(m / z)$ : calculated value for $\left[\mathrm{M}+\mathrm{H}^{+}\right] 609.7758$; found 609.3117 .

4-[-2-hydroxy-3-(morpholin-4-yl)propyl]-1,7,8,9-tetraphenyl-4-azatricyclo[5.2.1.0 $\left.{ }^{2,6}\right]$ dec8-ene-3,5-dione (3g)

M.W. $=610.7407$ (free amine); $\mathrm{C}_{40} \mathrm{H}_{38} \mathrm{~N}_{2} \mathrm{O}_{3}{ }^{*} \mathrm{HCl}$; Yield: $64 \%$; white powder, m.p. 276$277^{\circ} \mathrm{C}$ (from MeOH/ $\left.(\mathrm{Et})_{2} \mathrm{O}\right) ;{ }^{1} \mathrm{HNMR}\left(300 \mathrm{MHz}, \mathrm{DMSO}-\mathrm{d}_{6}+\mathrm{TMS}, \delta / \mathrm{ppm}\right): 2.34(1 \mathrm{H}, m$, C6-H), 3.07 ( $3 \mathrm{H}, m,-\mathrm{CH}_{2}$-morpholin, $\left.\mathrm{C} 2-\mathrm{H}\right), 3.29\left(5 \mathrm{H}, m,-\mathrm{CH}_{2}\right.$-morpholin, $\left.\mathrm{C} 10-\mathrm{H}\right), 3.46$ $\left(3 \mathrm{H}, m, \mathrm{C}^{\prime}-\mathrm{H}, \mathrm{C} 2^{\prime}-\mathrm{H}\right), 3.73\left(3 \mathrm{H}, m, \mathrm{C1}^{\prime}-\mathrm{H}, \mathrm{C} 10-\mathrm{H}\right), 3.92\left(2 \mathrm{H}, m,-\mathrm{CH}_{2}\right.$-morpholin), $6.48(4 \mathrm{H}$, $m, \mathrm{Ar}-\mathrm{H}), 6.88(6 \mathrm{H}, m, \mathrm{Ar}-\mathrm{H}), 7.31(6 \mathrm{H}, m, \mathrm{Ar}-\mathrm{H}), 7.74(4 \mathrm{H}, m, \mathrm{Ar}-\mathrm{H}), 10.45\left(1 \mathrm{H}\right.$, br.s, $\left.-\mathrm{NH}^{+}\right)$; ${ }^{13}$ CNMR: $\delta$ 21.22.0, 50.7, 51.9, 52.7, 58.9, 61.9, 63.0, 65.0, 126.5, 126.8, 127.2, 127.8, 129.1, 129.5, 145.1, 176.6, 176.9; HRMS $(m / z)$ : calculated value for $\left[\mathrm{M}+\mathrm{H}^{+}\right]$611.7486; found 611.2904.

\subsubsection{Preparation of Acetate Salt of Derivatives Ic, Ie, II}

Alkylamine derivatives were obtained according to the methods published previously $[9,10]$. Next, the appropriate derivative $(0.01 \mathrm{~mol})$ was dissolved in acetic acid $(60 \%)$ and heated to boiling. After cooling, the excess acid was evaporated to give a crystalline precipitate.

Acetate of 4-[2-(piperidin-1-yl)ethyl]-1,7-diethyl-8,9-diphenyl-4-azatricyclo[5.2.1.0 $\left.{ }^{2,6}\right]-$ dec8-ene-3,5,10-trione $\left(\mathrm{Ic}^{*} \mathrm{CH}_{3} \mathrm{COOH}\right)$

M.W. $=496.2720$ (free amine); $\mathrm{C}_{32} \mathrm{H}_{36} \mathrm{~N}_{2} \mathrm{O}_{3}{ }^{*} \mathrm{CH}_{3} \mathrm{COOH}$; Yield: 64\%; white powder, m.p. 85$89^{\circ} \mathrm{C}$ (from $\left.\mathrm{CH}_{3} \mathrm{COOH}\right) ;{ }^{1} \mathrm{HNMR}\left(300 \mathrm{MHz}, \mathrm{CDCl}_{3}, \delta / \mathrm{ppm}\right): 0.99\left(6 \mathrm{H}, t,-\mathrm{CH}_{3}, J=7.5 \mathrm{~Hz}\right)$, $1.46\left(2 \mathrm{H}, m,-\mathrm{CH}_{2}-\right), 1.62\left(4 \mathrm{H}, m,-\left(\mathrm{CH}_{2}\right)_{2}-\right), 2.02\left(2 \mathrm{H}, m,-\mathrm{CH}_{2}\right.$-piper $), 2.19\left(2 \mathrm{H}, \mathrm{m},-\mathrm{CH}_{2}-\right)$, $2.67\left(4 \mathrm{H}, \mathrm{m},-\mathrm{CH}_{2}\right.$-piper), $3.48(2 \mathrm{H}, m, \mathrm{C} 2-\mathrm{H}, \mathrm{C} 6-\mathrm{H}), 3.52\left(2 \mathrm{H}, m,-\mathrm{CH}_{2}\right.$-piper $), 3.74(2 \mathrm{H}, m$, - $\mathrm{CH}_{2}$-piper), $6.90(4 \mathrm{H}, m, \mathrm{Ar}-\mathrm{H}), 7.14(6 \mathrm{H}, m, \mathrm{Ar}-\mathrm{H}) ;{ }^{13} \mathrm{CNMR}: \delta$ 9.0, 18.9, 23.7, 25.2, 36.2, $43.5,53.8,55.2,59.3,127.4,127.9,129.1,133.5,141.5,176.0,199.8$; HRMS $(m / z)$ : calculated value for $\left[\mathrm{M}+\mathrm{H}^{+}\right]$497.2799; found 498.2799 .

Acetate of 4-[2-hydroxy-3-(propan-2-ylamino)propyl]-1,7-diethyl-8,9-diphenyl-4-azatricyclo [5.2.1. $\left.{ }^{2,6}\right]$ dec-8-ene-3,5,10-trione $\left(\mathrm{Ie} * \mathrm{CH}_{3} \mathrm{COOH}\right)$

M.W. $=500.2669$ (free amine); $\mathrm{C}_{31} \mathrm{H}_{36} \mathrm{~N}_{2} \mathrm{O}_{4}{ }^{*} \mathrm{CH}_{3} \mathrm{COOH}$; Yield: 77\%; white powder, m.p. 156-158 ${ }^{\circ} \mathrm{C}$ (from $\left.\mathrm{CH}_{3} \mathrm{COOH}\right) ;{ }^{1} \mathrm{HNMR}\left(300 \mathrm{MHz}, \mathrm{CDCl}_{3}, \delta / \mathrm{ppm}\right): 0.89\left(6 \mathrm{H}, t,-\mathrm{CH}_{3}\right.$, $J=7.5 \mathrm{~Hz}), 1.24\left(6 \mathrm{H}, d,-\mathrm{CH}_{3}, J=6.3 \mathrm{~Hz}\right), 2.00(2 \mathrm{H}, m,-\mathrm{CH} 2-), 2.19\left(2 \mathrm{H}, m,-\mathrm{CH}_{2}-\right), 2.80(1 \mathrm{H}$, $\left.m, \mathrm{C1}^{\prime}-\mathrm{H}\right), 2.89\left(1 \mathrm{H}, m, \mathrm{C1}^{\prime}-\mathrm{H}\right), 3.11(1 \mathrm{H}, m,-\mathrm{CH}-), 3.57\left(3 \mathrm{H}, m, \mathrm{C}^{\prime}-\mathrm{H}, \mathrm{C}^{\prime}-\mathrm{H}\right), 3.65(2 \mathrm{H}, m$, C2-H, C6-H), $4.17(1 \mathrm{H}, m,-\mathrm{OH}), 6.87(4 \mathrm{H}, m, \mathrm{Ar}-\mathrm{H}), 7.17$ (6H, $m, \mathrm{Ar}-\mathrm{H}),{ }^{13} \mathrm{CNMR}: \delta 9.0,18.9$, 21.7, 43.5, 48.4, 50.0, 59.2, 65.7, 127.3, 127.9, 129.2, 133.5, 141.7, 172.7, 176.2, 198.9; HRMS $(\mathrm{m} / \mathrm{z})$ : calculated value for $\left[\mathrm{M}+\mathrm{H}^{+}\right] 501.2748$; found 501.2748.

Acetate of 4-[2-(dimethylamino)ethyl]-1,7,8,9-tetraphenyl-4-azatricyclo[5.2.1.0 $\left.{ }^{2,6}\right]$ dec-8ene-3,5-dione $\left(\mathrm{II}^{*} \mathrm{CH}_{3} \mathrm{COOH}\right)$

M.W. $=538.2614$ (free amine) $; \mathrm{C}_{37} \mathrm{H}_{34} \mathrm{~N}_{2} \mathrm{O}_{2}{ }^{*} \mathrm{CH}_{3} \mathrm{COOH}$, Yield: 82\%; white powder, m.p. 203-205 ${ }^{\circ} \mathrm{C}$ (from $\left.\mathrm{CH}_{3} \mathrm{COOH}\right) ;{ }^{1} \mathrm{HNMR}\left(300 \mathrm{MHz}, \mathrm{CDCl}_{3}, \delta / \mathrm{ppm}\right): 2.32(6 \mathrm{H}, m,-\mathrm{CH} 3)$, $2.35(1 \mathrm{H}, m, \mathrm{C} 10-\mathrm{H}), 2.65\left(2 \mathrm{H}, t, J=6.3, \mathrm{C}^{\prime}-\mathrm{H}\right), 3.17(1 \mathrm{H}, m, \mathrm{C} 10-\mathrm{H}), 3.64(2 \mathrm{H}, t, J=6.3$, $\left.\mathrm{C} 2^{\prime}-\mathrm{H}\right), 4.18(2 \mathrm{H}, \mathrm{s}, \mathrm{C} 2-\mathrm{H}, \mathrm{C} 6-\mathrm{H}), 6.55(4 \mathrm{H}, m, \mathrm{Ar}-\mathrm{H}), 6.92(6 \mathrm{H}, m, \mathrm{Ar}-\mathrm{H}), 7.27$ (6H, $\left.m, \mathrm{Ar}-\mathrm{H}\right)$, 7.72 (4H, $m$, Ar-H); ${ }^{13} \mathrm{CNMR}: \delta 21.0,36.5,44.8,51.8,55.7,63.0,65.3,126.4,126.7,127.1,127.7$, 
129.1, 129.5, 134.3, 139.8, 144.9, 176.6; HRMS $(m / z)$ : calculated value for $\left[\mathrm{M}+\mathrm{H}^{+}\right]$539.2693; found 539.2693 .

\subsubsection{Determination of Lipophilicity by Reversed-Phase Chromatography}

The reversed-phase high-performance liquid chromatography (RP-HPLC) analysis was performed on a Merck-Hitachi LaChrom Elite System (Merck, Darmstadt, Germany) with diode array detector L-2455, thermostat L-2300, pump L-2130, and autosampler L-2200 and with the Waters XTerra MS RP-18 $(3.5 \mu \mathrm{m}, 150 \times 4.6 \mathrm{~mm})$ chromatographic column (Waters, Milford, MA, USA) as the stationary phase. The mobile phase consisted of methanol, water, and $0.1 \%(v / v)$ formic acid and was degassed by the use of the built-in membrane degasser. The methanol gradient grade for HPLC was purchased from Merck (Merck, Darmstadt, Germany) and formic acid from Polish Reagents (Polish Reagents, Gliwice, Poland); double-distilled water was used. Then, $5 \mu \mathrm{L}$ of methanolic solutions $(0.1 \% ; m / v)$ of selected samples were applied to the chromatographic column by the use of an autosampler Hitachi L-2200 (LaChrom Elite, Hitachi-Merck, Darmstadt, Germany). The analysis was performed with the flow rate of $0.7 \mathrm{~mL} \mathrm{~min}^{-1}$ in isocratic mode using various concentrations of organic modifier (methanol) in binary polar mobile phases; percentages of methanol in water were $45-70 \%(\%, v / v)$ and changed by $5 \%$ per step. Chromatograms were detected at $254 \mathrm{~nm}$ and the temperature of the column was $25^{\circ} \mathrm{C}$. All experiments were repeated in triplicate, and the final results were taken to be the arithmetic means. Dead time was measured by the use of uracil (Calbiochem. Merck, Darmstadt, Germany). Statistical and regression analyses were performed using Statistica (ver. 13.3 for Windows). The chromatographic lipophilicity parameters $\left(\log k_{W}\right)$ for selected samples were obtained by the extrapolation of the retention parameter $\log k$ to pure water, according to Equation (1):

$$
\log k=\log k_{w}-S \cdot \phi ;
$$

where $\log k_{W}$ is the value of the retention factor of a substance in pure water, $S$ is the slope of the regression curve, and $\phi$ is the concentration of the organic modifier [33]. The values of $\log k$ were calculated based on the raw HPLC data using the formula (2):

$$
\log k=\log \left(\frac{t_{R}-t_{0}}{t_{0}}\right) ;
$$

where $t_{R}$ is the retention time and $t_{0}$ is the dead retention time (determined for uracil).

\subsection{Anticancer Activity}

\subsubsection{Cells and Cytotoxicity Assay}

Human umbilical vein endothelial cells (Life Technologies, Carlsbad, CA, USA) were cultured (according to the manufacturer's instructions) in Medium 200 containing low serum growth supplement; $1 \times 10^{4}$ cells were seeded on each well on a 96-well plate (Nunc, Roskilde, Denmark). The HeLa (human cervix carcinoma), K562, and MOLT-4 (leukemia) cells were cultured in RPMI 1640 medium supplemented with antibiotics and $10 \%$ fetal calf serum in a $5 \% \mathrm{CO}_{2}-95 \%$ air atmosphere; $7 \times 10^{3}$ cells were seeded on each well on a 96-well plate (Nunc). Twenty-four hours later, cells were exposed to the test compounds for additional 48 hours. Stock solutions of test compounds were freshly prepared in DMSO. The final concentrations of the compounds tested in the cell cultures were $2 \times 10^{-1}$, $1 \times 10^{-1}, 5 \times 10^{-2}, 1 \times 10^{-2}, 1 \times 10^{-3}$, and $1 \times 10^{-4} \mathrm{mM}$. The concentration of DMSO in the cell culture medium was $1 \%$. The values of $\mathrm{IC}_{50}$ (the concentration of test compound required to reduce the cell survival fraction to $50 \%$ of the control) were calculated from dose-response curves and used as a measure of cellular sensitivity to a given treatment. The cytotoxicity of all compounds was determined by the MTT [3-(4,5-dimethylthiazol-2yl)-2,5-diphenyltetrazolium bromide; Sigma, St. Louis, MO, USA] assay. Briefly, after 24 or $48 \mathrm{~h}$ of incubation with drugs, the cells were treated with the MTT reagent, and incubation was continued for $2 \mathrm{~h}$. MTT-formazan crystals were dissolved in 20\% SDS and 50\% DMF 
at $\mathrm{pH}$ 4.7, and absorbance was read at 570 and $650 \mathrm{~nm}$ on a microplate reader FLUOstar Omega (BMG Labtech, Offenburg, Germany). As a control (100\% viability), we used cells grown in the presence of the vehicle (1\% DMSO) only.

\subsubsection{Analysis of Cell Apoptosis by Caspase-3/7 Activity Assay}

First, $20 \times 10^{3} \mathrm{~K} 562$ cells were seeded on each well of a 96-well plate in RPMI 1640 medium supplemented with $10 \%$ fetal calf serum and antibiotics. Cells were grown for $24 \mathrm{~h}$ at $37^{\circ} \mathrm{C}$ and $5 \% \mathrm{CO}_{2}$. Test dicarboximides were dissolved in DMSO and added to cell culture to the final concentration of $5 \times \mathrm{IC}_{50}$. Cells treated with $1 \%$ DMSO served as a negative control, while cells incubated with staurosporine (Sigma, St. Louis, MO, USA) were used as a positive control. Cells were exposed to test compounds for $18 \mathrm{~h}$ at $37{ }^{\circ} \mathrm{C}$ and $5 \% \mathrm{CO}_{2}$. Subsequently, the activity of caspase 3 and 7 was measured by Apo-ONE ${ }^{\circledR}$ Homogeneous Caspase-3/7 Assay (Promega, Madison, WI, USA) according to the manufacturer's instructions. Briefly, the cells were lysed and incubated for $1.5 \mathrm{~h}$ with a profluorescent substrate for caspase 3 and 7. Next, the fluorescence was read at an excitation wavelength of $485 \mathrm{~nm}$ and emission of $520 \mathrm{~nm}$ with a FLUOStar Omega microplate reader (BMG-Labtech, Offenburg, Germany).

\subsubsection{Gene Expression Analysis with DNA Microarray}

The expression of apoptotic genes was studied using predesigned 384-well microfluidic cards (TLDA TaqMan ${ }^{\circledR}$ human apoptosis array, Life Technologies, Applied Biosystems, Foster City, CA, USA). The RT-PCR experiments were executed twice, each on three separate TLDA plates. K562 tumor cells were seeded on a six-well plate (Nunc) in an amount of $3 \times 10^{6}$ cells/well and were exposed to the test compounds at a concentration of $5 \times \mathrm{IC}_{50}$ for another $18 \mathrm{~h}$. The control cells were exposed to $1 \%$ DMSO or $1 \mu \mathrm{M}$ staurosporine. The total RNA pool was isolated from the cell lysates using TriPure Isolation Reagent (Roche, Basel, Switzerland) according to the manufacturer's instruction. The RNA quality was checked with a NanoDrop ND-1000 spectrophotometer (Thermo Fisher Scientific, Waltham, MA, USA). Two micrograms of total RNA were reverse transcribed using a High Capacity cDNA Reverse Transcription kit (Applied Biosystems, Life Technologies). The 384-well TLDA (the qRT-PCR based TaqMan low-density array) cards were configured into four identical 96-gene sets consisting of 93 human genes and three endogenous controls: 18S, ACTB, and GAPDH. The primers (TaqMan Gene Expression Assay, Applied Biosystems) were selected to produce amplicons not longer than $100 \mathrm{bp}$ (a mean of $74 \mathrm{bp}$ ). Those 93 genes were categorized into multiple classes including intrinsic, extrinsic, regulatory, and execution apoptosis traits. A reaction mixture with a cDNA template $(100 \mathrm{ng})$ and an equal volume of TaqMan ${ }^{\circledR}$ universal master mix (Applied Biosystems) was immediately loaded into each line of the TLDA microfluidic card. Each card was spun twice (each time for $1 \mathrm{~min}$ ) at $1200 \mathrm{rpm}$, then was sealed and loaded into an ABI 7900HT fast real-time PCR system (Applied Biosystems, Waltham, MA, USA), operating for $2 \mathrm{~min}$ at $50{ }^{\circ} \mathrm{C}, 10 \mathrm{~min}$ at $94.5^{\circ} \mathrm{C}, 30 \mathrm{~s}$ at $97^{\circ} \mathrm{C}$, and $1 \mathrm{~min}$ at $59.7^{\circ} \mathrm{C}$ (40 cycles). The results were statistically analyzed using the Student's $t$-test, assuming a level of significance value of $p<0.05$. The MetaCoreTM software (Thomson Reuters, from GeneGo) was used to perform the pathway analysis of the differentially expressed genes.

\subsubsection{MAPKs Immunoblotting}

First, $2 \times 10^{6} \mathrm{~K} 562$ cells per well were seeded on a six-well plate in the complete medium (RPMI $1640+10 \%$ FBS). Then, $20 \mu \mathrm{M}$ JNK kinase inhibitor SP600125 or $10 \mu \mathrm{M}$ p38 inhibitor SB203580 (Cell Signaling Technology, Danvers, MA, USA) was added for $24 \mathrm{~h}$. Alternatively, K562 cells were exposed to $1 \%$ DMSO (control sample), test compound Ic $(6 \mu \mathrm{M})$, II $(3 \mu \mathrm{M})$, or staurosporine $(1 \mu \mathrm{M})$ for $18 \mathrm{~h}$. Cells exposed to staurosporine served as a positive control in ERK1/2 experiments. K562 cells treated with $20 \mu \mathrm{M}$ anisomycin (BioShop, Burlington, ON, Canada) for 30 min served as a positive control in JNK and p38 experiments. After incubation, cells were centrifuged ( $\left.600 \mathrm{rpm}, 6 \mathrm{~min}, 24^{\circ} \mathrm{C}\right)$, washed 
once with PBS, and lysed in the buffer containing $20 \mathrm{mM}$ Tris ( $\mathrm{pH} 7.5), 150 \mathrm{mM} \mathrm{NaCl}$, and $1 \%$ Triton $\mathrm{X}-100$, containing protease (complete protease inhibitor cocktail, Roche) and phosphatase inhibitors (PhosSTOP phosphatase inhibitor cocktail, Roche). Cells were lysed for $10 \mathrm{~min}$ on ice and centrifuged $\left(12,000 \mathrm{rpm}, 10 \mathrm{~min}, 4^{\circ} \mathrm{C}\right)$, and supernatants were collected. Total protein concentration in cell lysates was measured with DC Protein Assay (Bio-Rad, Hercules, CA, USA). Cell lysates containing $25 \mu \mathrm{g}$ of total protein were mixed with Laemli buffer supplemented with SDS and $\beta$-Mercaptoethanol, denatured (10 min, $95^{\circ} \mathrm{C}$ ), and subjected to SDS-PAGE electrophoresis (4\% stacking and 10\% resolving gels). Resolved proteins were electrotransferred (semi-dry, $90 \mathrm{~min}, 1.5 \mathrm{~mA} / \mathrm{cm}^{2}$ ) to nitrocellulose membranes $(0.45 \mu \mathrm{m}$, ThermoScientific). Membranes were blocked for $2 \mathrm{~h}$ in TBST buffer (20 mM Tris- $\mathrm{HCl}$ pH 7.5, 0.9\% NaCl, 0.1\% Tween 20) containing 5\% BSA (BioShop) and probed with primary antibodies (overnight at $4{ }^{\circ} \mathrm{C}$ ) diluted in TBST buffer with $0.5 \%$ BSA. Tubulin served as a loading control for IB experiments. Anti-phospho ERK1/2 (rabbit polyclonal, dilution 1:1000) and anti-ERK1/2 (rabbit polyclonal, dilution 1:1000) were from Cell Signaling Technology. Anti-phospho JNK (mouse polyclonal, dilution 1:250) and anti-JNK (mouse polyclonal, dilution 1:250) were from Santa Cruz Biotechnology (Dallas, TX, USA). Anti-phospho p38 (mouse polyclonal, dilution 1:250) and anti-p38 (mouse polyclonal, dilution 1:250) were from BD Transduction Laboratories (San Diego, CA, USA). Anti- $\alpha$-tubulin (mouse monoclonal IgG, 1:2000) was from Sigma. After extensive washing with the TBST buffer, membranes were probed with secondary goat anti-rabbit (1:5000 in TBST buffer) or goat anti-mouse HRP-conjugated IgG (1:5000 in TBST buffer, from Santa Cruz Biotechnology) for $45 \mathrm{~min}$ at room temperature. Membranes were washed in the TBST buffer, and the chemiluminescent signal was developed with ECL Plus Western Blotting Substrate (Thermo Scientific, Waltham, MA, USA) and visualized in a Syngene G:Box detection system.

\subsubsection{Digestion of Plasmid DNA with BamHI Restriction Nuclease}

First, $0.5 \mu \mathrm{g}$ of plasmid DNA (pcDNAHisC, total length $5.5 \mathrm{kbp}$ ) containing a unique $\mathrm{BamHI}$ restriction site was dissolved in a $1 \times \mathrm{BamHI}$ reaction buffer and incubated overnight at $37^{\circ} \mathrm{C}$ with the test compounds or daunorubicin. Daunorubicin, a strong intercalating agent, was used as a positive control. The concentration of the test compounds and daunorubicin samples was $100 \mu \mathrm{M}$. In the next step, the reaction mixtures were digested with $\mathrm{BamHI}$ restriction endonuclease $(2 \mathrm{U} / \mu \mathrm{L})$ for $3 \mathrm{~h}$ at $37^{\circ} \mathrm{C}$. The total reaction volume was $10 \mu \mathrm{L}$. Products of the reaction were subjected to the $1 \%$ agarose gel electrophoresis in TBE buffer. The gel was stained with ethidium bromide, and DNA fragments were visualized under a UV lamp (GBox, Syngene).

Supplementary Materials: Supplementary Materials are available online at https://www.mdpi. com/article/10.3390/ijms22094318/s1.

Author Contributions: Conceptualization: M.C., M.N., and B.N.; methodology: M.C. and M.N.; validation: M.C., M.N., and I.W.; investigation: M.C., M.N., J.K.-B., K.K.-G., I.W., and A.H.; resources: M.C., M.N., B.N., and I.W.; data curation: M.C., M.N., and I.W.; writing-original draft preparation: M.C. and M.N.; writing—review and editing: M.C., M.N., and B.N.; visualization: M.C. and M.N.; supervision: M.C., M.N., and B.N.; project administration: M.C., M.N., and B.N.; funding acquisition: M.N. and B.N. All authors have read and agreed to the published version of the manuscript.

Funding: This research was funded by the National Science Centre in Poland, project number UMO2014/15/B/NZ7/00966 (for B.N. and M.N.), by statutory funds of the Centre of Molecular and Macromolecular Studies, Polish Academy of Sciences, and by Warsaw Medical University.

Institutional Review Board Statement: Not applicable.

Informed Consent Statement: Not applicable.

Data Availability Statement: Not applicable. 
Acknowledgments: The cytotoxicity, activation of caspases, and DNA interaction studies were performed in the Screening Laboratory at the Department of Bioorganic Chemistry, Centre of Molecular and Macromolecular Studies of the Polish Academy of Sciences (CMMS PAS). The cost of this publication was covered in part by the statutory funds of CMMS PAS. The authors wish to thank Markus Düchler for revising the manuscript.

Conflicts of Interest: The authors declare no conflict of interest.

\section{References}

1. Didkowska, J.; Wojciechowska, U.; Zatoński, W. Prediction of Cancer Incidence and Mortality in Poland Up to the Year 2025. Warszawa 2009, ISSN 0867-8251. Available online: http:/ / onkologia.org.pl/wp-content/uploads/Prognozy_2025.pdf (accessed on 20 April 2021).

2. Bray, F.; Ferlay, J.; Soerjomataram, I.; Siegel, R.L.; Torre, L.A.; Jemal, A. Global cancer statistics 2018: GLOBOCAN estimates of incidence and mortality worldwide for 36 cancers in 185 countries. CA Cancer J. Clin. 2018, 68, 394-424. [CrossRef] [PubMed]

3. Hall, I.H.; Wong, O.T.; Scovill, J.P. The cytotoxicity of N-pyridinyl and N-quinolinyl substituted derivatives of phthalimide and succinimide. Biomed. Pharmacother. 1995, 49, 251-258. [CrossRef]

4. Luzina, E.L.; Popov, A.V. Synthesis and anticancer activity evaluation of 3,4-mono- and bicyclosubstituted N-(het)aryl trifluoromethyl succinimides. J. Fluor. Chem. 2014, 168, 121-127. [CrossRef] [PubMed]

5. Lee, J.-Y.; Chung, T.-W.; Choi, H.-J.; Lee, C.H.; Eun, J.S.; Han, Y.T.; Choi, J.-Y.; Kim, S.-Y.; Han, C.-W.; Jeong, H.-S.; et al. A novel cantharidin analog $N$-Benzylcantharidinamide reduces the expression of MMP-9 and invasive potentials of Hep3B via inhibiting cytosolic translocation of HuR. Biochem. Biophys. Res. Commun. 2014, 447, 371-377. [CrossRef]

6. Kok, S.H.L.; Gambari, R.; Chui, C.H.; Yuen, M.C.W.; Lin, E.; Wong, R.S.M.; Lau, F.Y.; Cheng, G.Y.M.; Lam, W.S.; Chan, A.S.C Synthesis and anti-cancer activity of benzothiazole containing phthalimide on human carcinoma cell lines. Bioorg. Med. Chem. 2008, 16, 3626-3631. [CrossRef]

7. Cardoso, M.V.D.O.; Moreira, D.R.M.; Filho, G.B.O.; Cavalcanti, S.M.T.; Coelho, L.C.D.; Espíndola, J.W.P.; Gonzalez, L.R.; Rabello, M.M.; Hernandes, M.Z.; Ferreira, P.M.P.; et al. Design, synthesis and structure-activity relationship of phthalimides endowed with dual antiproliferative and immunomodulatory activities. Eur. J. Med. Chem. 2015, 96, 491-503. [CrossRef]

8. Millrine, D.; Kishimoto, T. A Brighter Side to Thalidomide: Its Potential Use in Immunological Disorders. Trends Mol. Med. 2017, 23, 348-361. [CrossRef]

9. Kuran, B.; Napiórkowska, M.; Kossakowski, J.; Cieślak, M.; Kaźmierczak-Barańska, J.; Królewska, K.; Nawrot, B. New, Substituted Derivatives of Dicarboximides and their Cytotoxic Properties. Anti-Cancer Agents Med. Chem. 2016, 16, 852-864. [CrossRef]

10. Kuran, B.; Krawiecka, M.; Kossakowski, J.; Cieslak, M.; Kazmierczak-Baranska, J.; Królewska, K.; Nawrot, B. Dicarboximides Derivatives for Use in the Treatment of Cancer. European Patent Application EP13176421, 13 July 2013.

11. Cieślak, M.; Kaźmierczak-Barańska, J.; Królewska-Golińska, K.; Napiórkowska, M.; Stukan, I.; Wojda, U.; Nawrot, B. New Thalidomide-Resembling Dicarboximides Target ABC50 Protein and Show Antileukemic and Immunomodulatory Activities. Biomolecules 2019, 9, 446. [CrossRef]

12. Budzisz, E.; Krajewska, U.; Rozalski, M.; Szulawska, A.; Czyz, M.; Nawrot, B. Biological evaluation of novel Pt(II) and Pd(II) complexes with pyrazole-containing ligands. Eur. J. Pharmacol. 2004, 502, 59-65. [CrossRef]

13. Xu, G.; He, Q.; Yang, B.; Hu, Y. Synthesis and Antitumor Activity of Novel 4-Chloro-3-Arylmaleimide Derivatives. Lett. Drug Des. Discov. 2009, 6, 51-55. [CrossRef]

14. Hsiang, Y.H.; Jiang, J.B.; Liu, L.F. Topoisomerase II-mediated DNA cleavage by amonafide and its structural analogs. Mol. Pharmacol. 1989, 36, 2550774.

15. Lipinski, C.A.; Lombardo, F.; Dominy, B.W.; Feeney, P.J. Experimental and computational approaches to estimate solubility and permeability in drug discovery and development settings. Adv. Drug Deliv. Rev. 2001, 46. [CrossRef]

16. Leeson, P.D.; Springthorpe, B. The influence of drug-like concepts on decision-making in medicinal chemistry. Nat. Rev. Drug Discov. 2007, 6, 881-890. [CrossRef]

17. Jan, R.; Chaudhry, G.-E.-S. Understanding Apoptosis and Apoptotic Pathways Targeted Cancer Therapeutics. Adv. Pharm. Bull. 2019, 9, 205-218. [CrossRef]

18. Manns, J.; Daubrawa, M.; Driessen, S.; Paasch, F.; Hoffmann, N.; Löffler, A.; Lauber, K.; Dieterle, A.; Alers, S.; Iftner, T.; et al. Triggering of a novel intrinsic apoptosis pathway by the kinase inhibitor staurosporine: Activation of caspase- 9 in the absence of Apaf. FASEB J. 2011, 25, 3250-3261. [CrossRef]

19. Kelley, S.K.; Ashkenazi, A. Targeting death receptors in cancer with Apo2L/TRAIL. Curr. Opin. Pharmacol. 2004, 4, 333-339. [CrossRef]

20. Su, L.; Liu, G.; Hao, X.; Zhong, N.; Zhong, D.; Liu, X.; Singhal, S. Death Receptor 5 and cellular FLICE-inhibitory protein regulate pemetrexed-induced apoptosis in human lung cancer cells. Eur. J. Cancer 2011, 47, 2471-2478. [CrossRef]

21. Amin, P.; Florez, M.; Najafov, A.; Pan, H.; Geng, J.; Ofengeim, D.; Dziedzic, S.A.; Wang, H.; Barrett, V.J.; Ito, Y.; et al. Regulation of a distinct activated RIPK1 intermediate bridging complex I and complex II in TNF $\alpha$-mediated apoptosis. Proc. Natl. Acad. Sci. USA 2018, 115, E5944-E5953. [CrossRef]

22. Petrie, E.J.; Czabotar, P.E.; Murphy, J.M. The Structural Basis of Necroptotic Cell Death Signaling. Trends Biochem. Sci. 2019, 44, 53-63. [CrossRef] 
23. Westphal, D.; Dewson, G.; Czabotar, P.E.; Kluck, R.M. Molecular biology of Bax and Bak activation and action. Biochim. Biophys. Acta (BBA) Mol. Cell Res. 2011, 1813, 521-531. [CrossRef]

24. Han, J.-W.; Flemington, C.; Houghton, A.B.; Gu, Z.; Zambetti, G.P.; Lutz, R.J.; Zhu, L.; Chittenden, T. Expression of bbc3, a pro-apoptotic BH3-only gene, is regulated by diverse cell death and survival signals. Proc. Natl. Acad. Sci. USA 2001, 98, 11318-11323. [CrossRef]

25. Li, Z.-W.; Chu, W.; Hu, Y.; Delhase, M.; Deerinck, T.J.; Ellisman, M.H.; Johnson, R.S.; Karin, M. The IKK $\beta$ Subunit of IkB Kinase (IKK) is Essential for Nuclear Factor кB Activation and Prevention of Apoptosis. J. Exp. Med. 1999, 189, 1839-1845. [CrossRef]

26. Makris, C.; Godfrey, V.L.; Krähn-Senftleben, G.; Takahashi, T.; Roberts, J.L.; Schwarz, T.; Feng, L.; Johnson, R.S.; Karin, M. Female Mice Heterozygous for IKK $\gamma /$ NEMO Deficiencies Develop a Dermatopathy Similar to the Human X-Linked Disorder Incontinentia Pigmenti. Mol. Cell 2000, 5, 969-979. [CrossRef]

27. Meloche, S.; Pouysségur, J. The ERK1/2 mitogen-activated protein kinase pathway as a master regulator of the G1- to S-phase transition. Oncogene 2007, 26, 3227-3239. [CrossRef]

28. Dhanasekaran, D.N.; Reddy, E.P. JNK signaling in apoptosis. Oncogene 2008, 27, 6245-6251. [CrossRef]

29. Thornton, T.M.; Rincon, M. Non-Classical P38 Map Kinase Functions: Cell Cycle Checkpoints and Survival. Int. J. Biol. Sci. 2009, 5, 44-52. [CrossRef]

30. Cuenda, A.; Rousseau, S. p38 MAP-Kinases pathway regulation, function and role in human diseases. Biochim. Biophys. Acta (BBA) Mol. Cell Res. 2007, 1773, 1358-1375. [CrossRef]

31. Eckert, F.; Klamt, A. Accurate prediction of basicity in aqueous solution with COSMO-RS. J. Comput. Chem. 2005, 27, 11-19. [CrossRef]

32. Kuran, B.; Krawiecka, M.; Kossakowski, J.; Koronkiewicz, M.; Chilmonczyk, Z. Proapoptotic activity of heterocyclic compounds containing succinimide moiety in the promyelocytic leukemia cell line HL-60. Acta Pol. Pharm. Drug Res. 2013, 70, 459-468.

33. Snyder, L.R.; Dolan, J.W.; Gant, J.R. Gradient Elution in High performance Liquid Chromatography: II. Practical Application to Reversed-phase Systems. J. Chromatogr. A 1979, 165, 31-58. [CrossRef] 